\title{
Palladium(0)-catalyzed syntheses of cyclopentenyl-nucleoside analogues
}

\author{
Paolo Quadrelli, Mariella Mella, Naiara Vazquez Martinez, and Andrea Piccanello \\ Dipartimento di Chimica Organica, Università degli Studi di Pavia \\ Viale Taramelli 10, 27100 - Pavia (Italy) \\ E-mail: paolo.quadrelli@unipv.it
}

\begin{abstract}
The $N$-benzoylamino-2-cyclopenten-1-ol, derived from the nitrosocarbonyl hetero Diels-Alder cycloaddition reaction followed by the mild reductive $\mathrm{N}-\mathrm{O}$ bond cleavage, allows for the preparation of cyclopentenyl-nucleoside analogues through the palladium(0)-catalyzed addition of both purine and pyrimidine heterobases to the allylic acetate derivative with retention of the starting material stereochemistry. A systematic study is performed on different heterobases to test the general application of the protocol.
\end{abstract}

Keywords: Nitrosocarbonyl, hetero Diels-Alder cycloaddition, palladium(0)-catalyzed reactions, heterobases, nucleoside analogues

\section{Introduction}

Because of the imperative defence from infections, there is the never ending demand of new antagonists and the intense current interest in the synthesis of carbocyclic nucleoside analogues, that are widely preferred due to their metabolic stability. ${ }^{1}$ During recent years, nucleoside targets have been investigated in the search of effective treatment for various herpes type viruses ${ }^{2}$ yielding a profusion of synthetic activity that helped both the understanding in action mechanisms and in widening the pharmacological applications. ${ }^{3}$ In fact, carbocyclic nucleosides have been the focus also in the development of new antitumor therapeutic agents ${ }^{4}$ as well as in the selective inhibition of human immunodeficiency virus (HIV). ${ }^{5}$ Moreover these compounds were taken into consideration as agrochemicals ${ }^{6}$ and as antifungal drugs ${ }^{7}$ because of their wide range of biological properties. The development of further effective therapeutic agents against Hepatitis $\mathrm{C}$ virus (HCV) is also an urgent public health requirement. ${ }^{8}$ Nevertheless, due to the not ignored toxicity, the use of these nucleosides has been limited in the clinical applications of human deseases. ${ }^{9}$ 
The discovery of new structures displaying increased activities and low toxicities is challenging various research groups and we have recently proposed a rapid access to carbocyclic nucleosides containing a fused isoxazoline ring starting from cyclopentadiene or 1,3cyclohexadiene. ${ }^{10}$ The route involves an hetero Diels-Alder (HDA) cycloaddition reaction of nitrosocarbonyl intermediates (R-CONO) followed by a 1,3-dipolar cycloaddion of nitrile oxides, cleavage of the $\mathrm{N}-\mathrm{O}$ tether and elaboration of the heterocyclic aminols into nucleosides via the linear construction of purine and pyrimidine heterocycles. The pivotal step is represented by the chemistry of nitrosocarbonyls that are fleeting intermediates and powerful dienophiles in HDA reactions. ${ }^{11}$ Cyclic dienes 1 efficiently trap these intermediates affording the HDA adducts 2 (Scheme 1) which were found highly reactive dipolarophiles. From the 1,3-dipolar cycloadducts 3 the stereoordinate anti aminols $\mathbf{4}$ were easily obtained and the heterobases were build up through appropriate reagents.

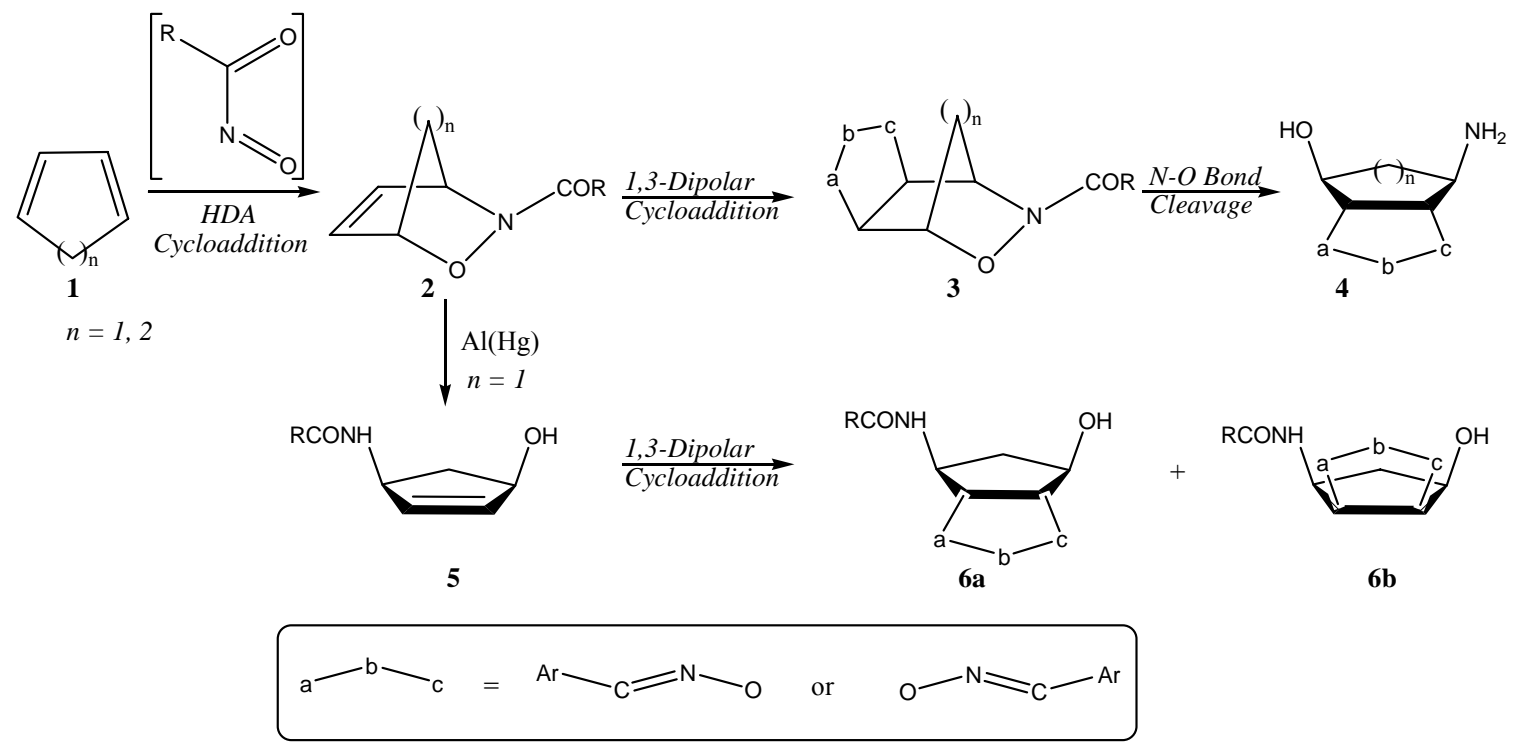

\section{Scheme 1}

Starting from the 2,3-oxazanorborn-5-ene HDA cycloadduct $2(n=1)$, the mild reductive cleavage of the $\mathrm{N}-\mathrm{O}$ bond with $\mathrm{Al}(\mathrm{Hg})$ afforded the stereodefined cis 4-amido-2-cyclopenten-1ol 5 whose 1,3-dipolar cycloadditions with nitrile oxides have been thoroughly investigated. ${ }^{12}$ It was found that the syn directing effect of the allylic $\mathrm{OH}$ and NHCOR groups is completely offset by a strong intramolecular hydrogen bond favoring the formation of cycloadducts $\mathbf{6 a}$. Removal of the intramolecular hydrogen bond by $\mathrm{OH}$ protection or oxidation of the alcoholic functionality activated the syn-directing ability of the amido substituent and provided a convenient syn stereoselective approach to cycloadduct $\mathbf{6 b}$.

On the basis of these results, we considered the possibility to employ the cyclopentenyl derivative 5 as an alternative source of C-carbo nucleosides. ${ }^{13}$ The strategy relies on the metalcatalyzed functionalization of the esters of cyclic allylic alcohols with nucleophiles, ${ }^{14}$ heterobases in the specific case. P. M. Woster and N. S. Sirisoma reported the use of the acetates 
of N-Boc protected 4-aminocycloalk-2-en-1-oles in $\operatorname{Pd}(0)$-catalyzed amination with benzylamine or phthalimide to give the corresponding protected amines. ${ }^{15} \mathrm{~B}$. M. Trost and co-workers described an enantioselective Pd-catalyzed desymmetrization of the benzoate of the ciscyclopent-ene-1,4-diol as a key-step towards the synthesis of (-)-Neplanocin, ${ }^{3 \mathrm{e}}$ while M. von Janta-Lipinski et al. prepared adenosine analogues through the use of the 4-phosphonates of cyclopent-2-en-1,4-dioles using Pd-tetrakis as catalyst. ${ }^{5 \mathrm{c}}$ The acetates of 5-substituted derivatives of cyclopent-2-ene-1-ols were also used to prepare nucleoside analogues as anti-HIV agents under Pd-catalyzed conditions by R. A. MacKeith ${ }^{5 \mathrm{e}}$ and by M. T. Crimmins. ${ }^{5 \mathrm{f}}$ A single application has been reported from a N-Boc protected 4-aminocyclopent-2-ene-1-ol acetate derivative obtained from 2,3-oxazanorbornene compound by M. J. Miller who detailed the Pdmediated functionalization with adenine. ${ }^{16}$ In all these as well as other cases ${ }^{14} \operatorname{Pd}(0)$ catalysts were efficiently used in the pivotal steps of the syntheses and the ready stereoselective substitution of the alcoholic moiety with heterobases represents an interesting evolution in the field of anti-viral agents with low cytotoxicity. ${ }^{17}$ The stereodefined cis 4-amido-2-cyclopenten-1ol 5 may be a useful synthon for the construction of nucleoside analogues and other derivatives through the easy functionalization of the $\mathrm{C}=\mathrm{C}$ double bond. This paper gives a detailed account on the convergent approach to a variety of both purine and pyrimidine carbocyclic derivatives through the palladium(0)-catalyzed protocol. A systematic study is performed on different heterocyclic bases to test the general application of the method.

\section{Results and Discussion}

The 4-benzoylamino-2-cyclopenten-1-ol acetate 7 is prepared according to the reported ${ }^{14 a}$ $\mathrm{Ac}_{2} \mathrm{O} / \mathrm{Et}_{3} \mathrm{~N} / \mathrm{DMAP}$ procedure in anhydrous dichloromethane (DCM) solution in quantitative yield. The substrate 7 , now bearing a good leaving group (OAc), smoothly reacts in the presence of catalytic $\mathrm{Pd}\left(\mathrm{PPh}_{3}\right)_{4}(5 \% \mathrm{~mol})$ in anhydrous dimethylformamide (DMF) solution at r.t. undergoing oxidative addition of the allylic cation, that coordinates to the $\operatorname{Pd}(0)$ complex (Scheme 2) ${ }^{5 \mathrm{~d}-\mathrm{e}, 13,14 \mathrm{f}, \mathrm{g}, 18}$ The newly formed $\pi$-allylic complex $\mathbf{8}$ adds the adenine sodium salt $\mathbf{1 0}$, previously generated in situ upon treatment of adenine 9 (1.2 equivs.) with a slight excess (1.5 equivs.) of $\mathrm{NaH}$ in DMF solution. The adenine salt addition occurs syn to the benzoylamine group as the Pd complex occupies the opposite face. As it is expected, the retention of the stereochemistry of the starting material $\mathbf{7}$ in the final products $\mathbf{1 1}$ is observed, which is in agreement with the reported examples. ${ }^{19}$ The reaction is left under stirring at r.t. for $18 \mathrm{~h}$ and the choice of Pd tetrakis was done on the basis of the best results obtained in literature for similar substrates. ${ }^{13,14,16,19}$ Upon quenching of the reaction with water and extraction with DCM, the crude reaction mixture is submitted to chromatographic separation on silica gel column by eluting with $\mathrm{CHCl}_{3}$ and then $\mathrm{CHCl}_{3} / \mathrm{MeOH}$ 9/1 mixtures. 


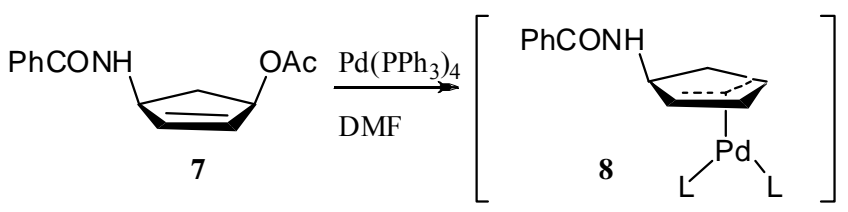<smiles>Nc1ncnc2[nH]cnc12</smiles><smiles></smiles><smiles>Nc1ncnc2c1ncn2-c1ccccc1</smiles>

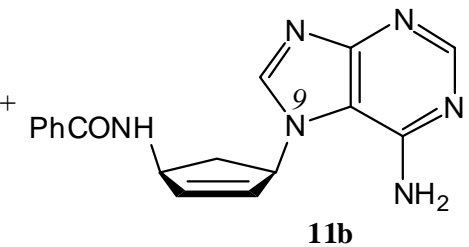

\section{Scheme 2}

Two isomeric adenine derivatives 11a,b were isolated in $42 \%$ and $35 \%$ yields, respectively. Their structures rely upon the analytical and spectroscopic data. In particular, the ${ }^{1} \mathrm{H}-$ and ${ }^{13} \mathrm{C}$ NMR spectra were consistent for a 1:1 ratio between the adenine and the cyclopentenyl moieties for compounds of general formula $\mathrm{C}_{17} \mathrm{H}_{16} \mathrm{~N}_{6} \mathrm{O}$. The isomeric nature of products 11a,b is related to the two possible orientations of the adenine salt $\mathbf{1 0}$ when adds the $\mathrm{Pd}$ complex, due to the anion delocalization between $\mathrm{N} 7$ and $\mathrm{N} 9$ in the heterobase moiety. Table 1 reports the representative chemical shifts for the two isomers 11a,b.

Table 1. ${ }^{1} \mathrm{H}$ - and ${ }^{13} \mathrm{C}-\mathrm{NMR}$ chemical shifts of compounds 11a,b

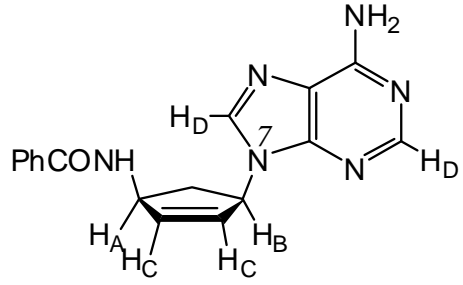

11a

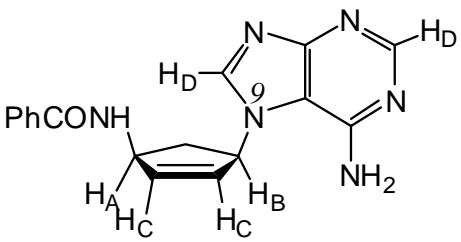

11b

\begin{tabular}{ccccc|cccc}
\hline & \multicolumn{4}{c|}{${ }^{1} \mathrm{H}-N M R^{\mathrm{a}}$} & \multicolumn{4}{c}{${ }^{13} \mathrm{C}-\mathrm{NMR}^{\mathrm{b}}$} \\
& $\mathrm{A}$ & $\mathrm{B}$ & $\mathrm{C}$ & $\mathrm{D}$ & $\mathrm{A}$ & $\mathrm{B}$ & $\mathrm{C}$ & $\mathrm{D}$ \\
\hline 11a & 5.38 & 5.69 & 6.02 & 8.08 & 55.1 & 60.9 & 132.1 & 141.8 \\
& & & 6.20 & 8.19 & & & 136.6 & 153.4 \\
11b & \multirow{2}{*}{5.28} & 5.77 & 6.05 & 7.84 & 53.8 & 65.0 & 130.2 & 142.9 \\
& & & 6.20 & 8.42 & & & 137.8 & 151.6 \\
\hline
\end{tabular}

${ }^{\mathrm{a}}$ Protons A, B and C are multiplets; protons D are singlets. ${ }^{\mathrm{b}}$ Carbons A-D are doublets. 
None of these data allowed to assign the correct stereochemistry. More concrete evidences were gained from further appropriate experiments. NOESY experiments confirmed the cis relative position in both the isomers 11a,b of the adenine moiety and the benzoylamino group. HMBC experiments allowed to find out the decisive connections via ${ }^{3} \mathrm{~J}_{\mathrm{C}-\mathrm{H}}$ between the proton $\mathrm{H}_{\mathrm{B}}$ at $5.69 \delta$ and the $\mathrm{C} 4$ at $150.4 \delta$ in the major isomer 11a and the proton $\mathrm{H}_{\mathrm{B}}$ at $5.77 \delta$ and the $\mathrm{C} 5$ at $148.7 \delta$ in the minor isomer 11b. ${ }^{3 f, 14,16}$

The 4-benzoylamino-2-cyclopenten-1-ol acetate 7 also reacts with the 6-chloropurine 12 under the same experimental conditions to afford, after the usual work-up and chromatographic separation, the chloropurine derivatives 13a,b in $47 \%$ and 13\% yields, respectively (Scheme 3).

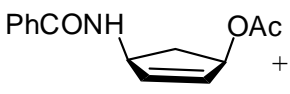

7

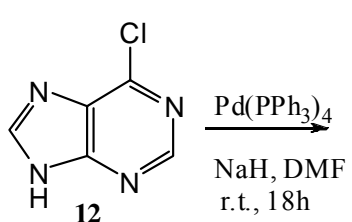

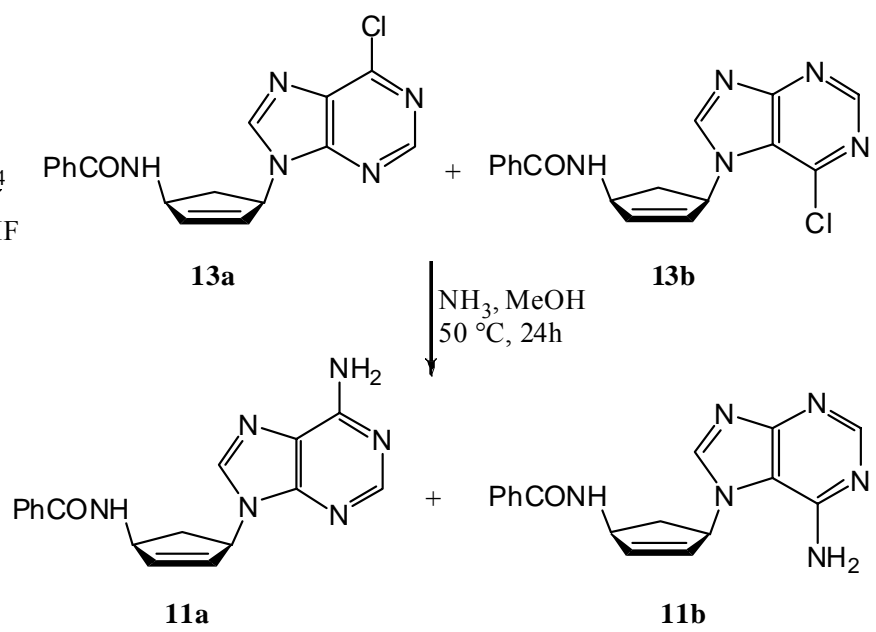

$11 \mathbf{b}$

\section{Scheme 3}

The structure of compound 13a relies upon the relative analytical and spectroscopic data. In particular, the ${ }^{1} \mathrm{H}$ - and ${ }^{13} \mathrm{C}-\mathrm{NMR}$ spectra were consistent for a $1: 1$ ratio between the 6chloroadenine 12 and the cyclopentenyl moieties for compounds of general formula $\mathrm{C}_{17} \mathrm{H}_{14} \mathrm{~N}_{5} \mathrm{OCl}$. The protons of the purine ring are found at 8.74 and $8.59 \delta$ while the rest of the signals belonging to the cyclopentenyl moiety are found in the usual range and the amide $\mathrm{NH}$ at $8.31 \delta$. NOESY experiments confirmed the cis relative position in the structure of 13a of the purine moiety and the benzoylamino group. The structure of compound $\mathbf{1 3 b}$ also relies upon the relative analytical and spectroscopic data. The ${ }^{1} \mathrm{H}$ - and ${ }^{13} \mathrm{C}-\mathrm{NMR}$ spectra were consistent for a 1:1 ratio between the 6-chloroadenine 12 and the cyclopentenyl moieties for compounds of general formula $\mathrm{C}_{17} \mathrm{H}_{14} \mathrm{~N}_{5} \mathrm{OCl}$. The protons of the purine ring are found at 8.77 and $8.65 \delta$ while the signals belonging to the cyclopentenyl moiety are found in the usual range and the amide $\mathrm{NH}$ at $8.01 \delta$.

From the chloro-purine nucleosides 13a,b, the adenide derivatives 11a,b could be obtained by simple treatment with ammonia in methanol at $50{ }^{\circ} \mathrm{C}$ for $24 \mathrm{~h}$ in a sealed flask. ${ }^{20}$ Products 11a,b were isolated in $89 \%$ and $76 \%$ yields, respectively, and found identical to the samples previosly prepared. 
From the major chloro-purine nucleoside 13a a variety of derivatives can be obtained by nucleophilic substitution. ${ }^{20}$ On heating $\mathrm{MeOH}$ solutions of 13a at $50{ }^{\circ} \mathrm{C}$ in the presence of an excess of differently substituted primary and secondary amines, the amino derivatives 14(a-d) could easily be obtained (Scheme 4).
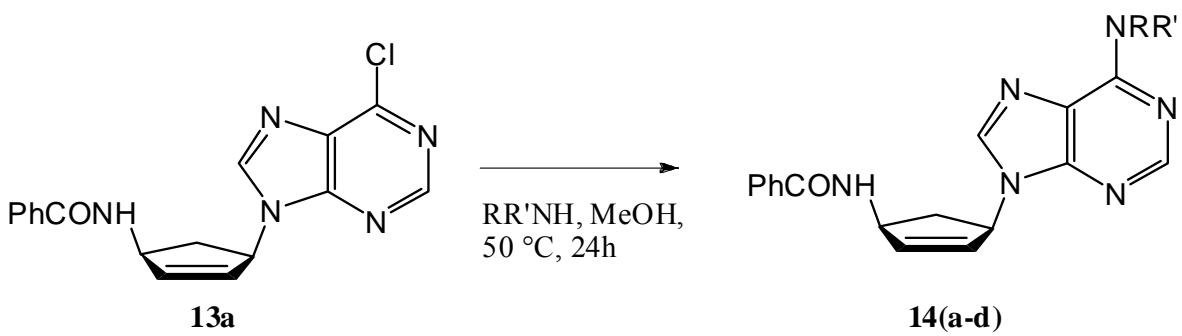

\section{Scheme 4}

Table 2 reports the chemical yields and physical constants of purine nucleosides 14(a-d) which have been fully characterized through their analytical and spectroscopic data.

Table 2. Yields and physical constants of purine derivatives 14(a-d)

\begin{tabular}{ccccc}
\hline $\mathbf{1 4}$ & $\mathrm{R}$ & $\mathrm{R}{ }^{\prime}$ & $\mathrm{mp}^{\circ} \mathrm{C}(\mathrm{Solv})$. & Yields \% \\
\hline $\mathbf{a}$ & $\mathrm{H}$ & $\mathrm{Me}$ & $\begin{array}{c}>210(\mathrm{dec} .) \\
\left(i \mathrm{Pr}_{2} \mathrm{O} / \mathrm{EtOH}\right)\end{array}$ & 99 \\
$\mathbf{b}$ & $\mathrm{Et}$ & $\mathrm{Et}$ & $\begin{array}{c}127-130 \\
\left(\mathrm{iPr} \mathrm{Pr}_{2} \mathrm{O} / \mathrm{EtOH}\right)\end{array}$ & 99 \\
$\mathbf{c}$ & $\mathrm{H}$ & $\mathrm{cPr}^{\S}$ & $\begin{array}{c}193-195 \\
\left(i \mathrm{Pr}_{2} \mathrm{O} / \mathrm{EtOH}\right)\end{array}$ & 98 \\
$\mathbf{d}$ & $\mathrm{H}$ & $\mathrm{CH}_{2} \mathrm{Ph}$ & $\begin{array}{c}202-205 \\
\left(i \mathrm{Pr}_{2} \mathrm{O} / \mathrm{EtOH}\right)\end{array}$ & 97 \\
\hline
\end{tabular}

$\S$. cPr - cyclopropyl

In all the cases the products show the characteristic purine $\mathrm{CH}=\mathrm{N}$ proton singlets ranging between 8.08 and $8.29 \delta$ and the benzoyl amide NH deshielded at 9.1-9.3 $\delta$. In compounds 14a,c a second NH proton is found at 6.87 and $6.80 \delta$, respectively, because of the new substitution on the position 6 of the purine ring with primary amines. The same type of proton was expected in product 14d where benzylamine was inserted on the 6-chloropurine ring; it is found deshielded on beneath the aromatic protons around $7.4 \delta$. The other proton belonging to the cyclopentenyl moiety and to the amine substituents are found in the usual ranges. To corroborate the cis relationship between the purine ring and the benzoylamido groups, NOESY experiments were performed showing cross-peaks between the amide $\mathrm{NH}$ proton and one of the two methylene 
protons of the cyclopentene ring while the other relates with the two $\mathrm{CH}-\mathrm{N}$ protons of the cyclopentene ring.

In order to test the application of the $\mathrm{Pd}\left(\mathrm{PPh}_{3}\right)_{4}$ catalyzed reactions as a general protocol for the synthesis of cyclopentenyl-nucleoside analogues, a few other purines 15a,b as well as benzoimidazole derivatives $\mathbf{1 5 c , d}$ have been tested in the reaction with the 4-benzoylamino-2cyclopenten-1-ol acetate 7 under the usual conditions (Scheme 5). Upon quenching of the reactions with water and extraction with DCM, the crude reaction mixture is submitted to chromatographic separation on silica gel column by eluting with $\mathrm{CHCl}_{3}-\mathrm{CHCl}_{3} / \mathrm{MeOH} 9 / 1$ mixtures. Table 3 reports the chemical yields and physical constants of purine nucleosides 16(ad) which have been fully characterized through their analytical and spectroscopic data.
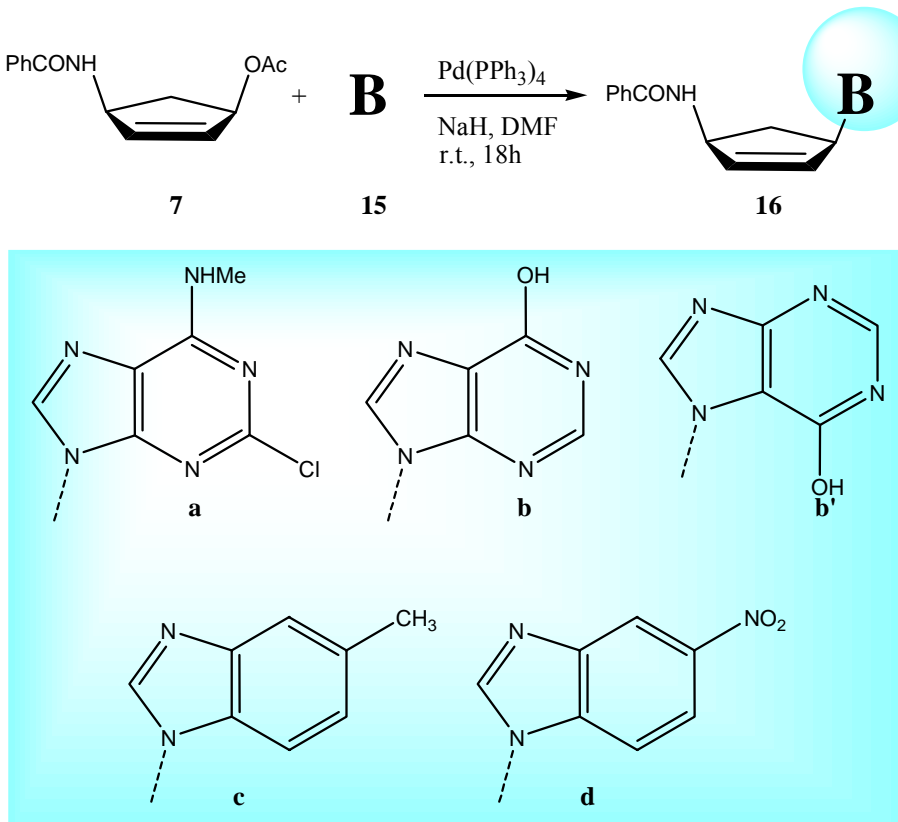

\section{Scheme 5}

Table 3. Yields and physical constants of purine derivatives 16(a-d)

\begin{tabular}{ccc}
\hline $\mathbf{1 6}$ & $\mathrm{mp}{ }^{\circ} \mathrm{C}\left(\mathrm{Solv}_{.}\right)$ & Yields $\%$ \\
\hline $\mathbf{a}$ & $>210($ dec. $)\left(i \mathrm{Pr}_{2} \mathrm{O}\right)$ & 60 \\
$\mathbf{b}$ & $>215($ dec. $)\left(i \mathrm{Pr}_{2} \mathrm{O}\right)$ & 37 \\
$\mathbf{b}^{\prime}$ & $>215($ dec. $)\left(i \mathrm{Pr}_{2} \mathrm{O}\right)$ & 12 \\
$\mathbf{c}$ & $110-112\left(i \mathrm{Pr}_{2} \mathrm{O} / \mathrm{EtOH}\right)$ & 10 \\
$\mathbf{d}$ & $179-181\left(i \mathrm{Pr}_{2} \mathrm{O} / \mathrm{EtOH}\right)$ & 66 \\
\hline
\end{tabular}

The ${ }^{1} \mathrm{H}-\mathrm{NMR}$ spectra of compound 16a nicely account for the reported structure with the two different $\mathrm{NH}$ groups, the more deshielded at $8.19 \delta$ corresponding to the amide moiety and the 
one at $7.81 \delta$ relative to the methylamine substituent of the purine ring, which gives also a singlet at $7.75 \delta$ for the imidazolic $\mathrm{CH}=\mathrm{N}$. The reaction with the 6-purinol gave two products $\mathbf{1 6} \mathbf{b}, \mathbf{b}$, regioisomeric at the N7 and N9 of the purine ring. The IR spectra of both the products show neat $\mathrm{OH}$ bands at 3277 (s) and 3250 (br) $\mathrm{cm}^{-1}$. In the ${ }^{1} \mathrm{H}-\mathrm{NMR}$ spectra (DMSO) the OH groups are strongly deshielded and are found at 12.34 and $11.75 \delta$ and the structure of the purinol ring is completed by the presence of the $\mathrm{CH}=\mathrm{N}$ protons in the expected region. However, we were unable to distinguish between the two possible structures of compounds 16b,b' beyond any reasonable doubt. All the HMBC experiments performed in order to establish which one is connected to the cyclohexene moiety through the N7 or N9 failed.

Finally two benzoimidazole derivatives 16c,d were prepared in variable yields. In $16 c$ the $\mathrm{CH}=\mathrm{N}$ proton of the benzoimidazole ring is found at $7.50 \delta$ along with other aromatic signals. The methyl group is also found at $2.45 \delta$. In 16d the $\mathrm{CH}=\mathrm{N}$ proton of the benzoimidazole ring is deshielded at $8.68 \delta$. For both $\mathbf{1 6 c}$ and $\mathbf{1 6 d}$ all the other signals are found in the expected regions.

Other heterobases, such as the 2-amino-6-chloropurine, guanine and hypoxanthine, have been tried under different conditions but without success. Presumably, the catalytic system has to be tuned up to perform the reactions with these or similar heterobases.

Besides the syntheses of the purine and benzoimidazole derivatives, we explored the application of the protocol for the preparation of pyrimidine nucleoside analogues. The experimental conditions previously introduced were not successful and the reactions took place only after heating overnight. ${ }^{14 \mathrm{c}}$ The uracils $\mathbf{1 7 a - e}$ and the thymines 17f,g were completely dissolved in anhydrous DMF at $65{ }^{\circ} \mathrm{C}$ and transformed into the corresponding sodium salts 18a-g upon addition of a slight excess (1.2 equivs.) of $\mathrm{NaH}$ at r.t. (Scheme 6).
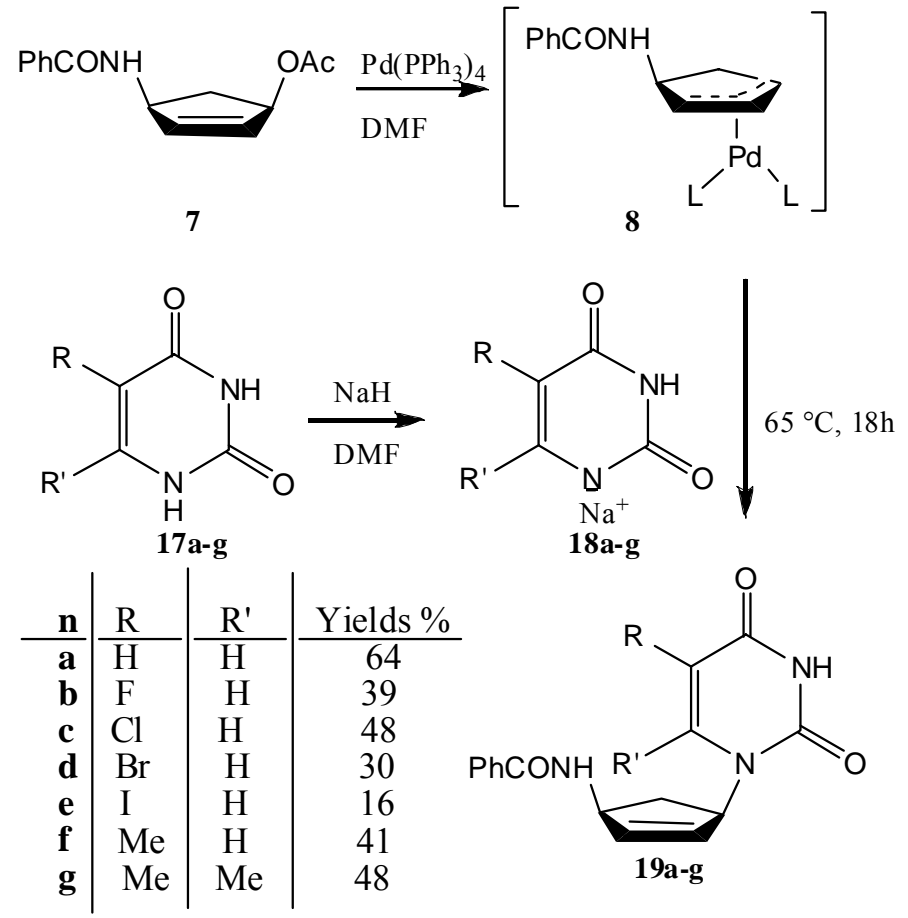

Scheme 6 
After stirring for 30 minutes at $65{ }^{\circ} \mathrm{C}$ to complete the reaction, the solution is cooled down and 1 equiv. of the substrate 7 is added along with one half equiv. of $\operatorname{Pd}\left(\mathrm{PPh}_{3}\right)_{4}$, both dissolved in anhydrous DMF. The reaction goes to completion by keeping at $65^{\circ} \mathrm{C}$ for $18 \mathrm{~h}$. After this period of time, quenching was done by addition of water and the solution was extracted with DCM. The residue, obtained upon evaporation of the solvent, was submitted to column chromatography (eluant: $\mathrm{CHCl}_{3}-\mathrm{CHCl}_{3} / \mathrm{MeOH}$ 9/1) to purify the products 19a-g, which were isolated from fair to good yields.

The analytical and spectroscopic data of 19a-g were consistent with the assigned structures. Table 4 reports the physical data and the most significative spectroscopic data. In the FT-IR spectra the bands corresponding to the NHCOPh and the CONHCO groups are cleary showed. In the ${ }^{1} \mathrm{H}-\mathrm{NMR}$ spectra the proton signals belonging to the cyclopentenyl moiety $\left(\mathrm{H}_{\mathrm{A}, \mathrm{B}, \mathrm{C}}\right)$ are in the range between 5.0-6.2 $\delta$. When $\mathrm{R}^{\prime}=\mathrm{H}$, the uracil moieties showed significantly the protons around 7.5-8.7 $\delta$ depending on the adjacent substitution. In the case of simple uracil derivative 14a an additional olefinic proton $(\mathrm{R}=\mathrm{H})$ signal is shown at $5.67 \delta$ as a double doublet coupled with that $\left(\mathrm{R}^{\prime}=\mathrm{H}\right)$ at $7.56 \delta(\mathrm{J}=8$ and $1.5 \mathrm{~Hz})$. Finally, the CONHCO is characterized by the $\mathrm{H}_{\mathrm{D}}$ proton signals highly deshielded in the region around 11-12 $\delta$.

Table 4. Physical and spectroscopic data of compounds 19a-g

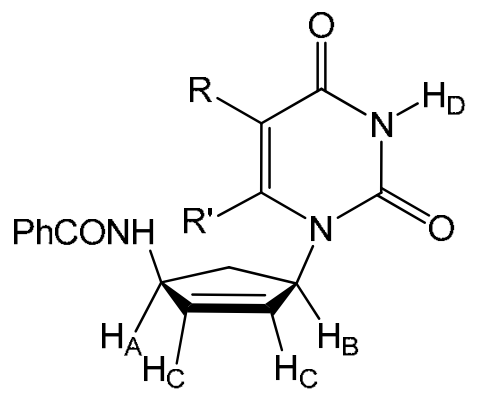

\begin{tabular}{cccccccc}
\hline \multirow{2}{*}{19} & m.p. $\left({ }^{\circ} \mathrm{C}\right)$ & FT-IR & \multicolumn{4}{c}{${ }^{1} \mathrm{H}-\mathrm{NMR}(\delta, \mathrm{ppm}$ in DMSO $)$} \\
\cline { 3 - 7 } & & $\mathrm{v}_{\mathrm{NH}}\left(\mathrm{cm}^{-1}\right)$ & $\mathrm{H}_{\mathrm{A}}$ & $\mathrm{H}_{\mathrm{B}}$ & $\mathrm{H}_{\mathrm{C}}$ & $\mathrm{R}^{\prime}$ & $\mathrm{H}_{\mathrm{D}}$ \\
\hline a & $217-220$ & $3425(\mathrm{br}), 3223(\mathrm{br})$ & 5.00 & 5.51 & $5.87,6.11$ & 7.56 & 11.29 \\
b & $78-80$ & $3370(\mathrm{br}), 3185(\mathrm{br})$ & 5.04 & 5.75 & $5.87,6.11$ & 8.32 & 11.12 \\
c & $147-150$ & $3310(\mathrm{br}), 3167(\mathrm{br})$ & 5.03 & 5.52 & $5.91,6.13$ & 8.67 & 11.85 \\
d & $230($ dec. $)$ & $3250(\mathrm{br}), 3150(\mathrm{br})$ & 5.02 & 5.52 & $5.91,6.15$ & 8.69 & 11.84 \\
e & $194($ dec. $)$ & $3310(\mathrm{br}), 3167(\mathrm{br})$ & 5.00 & 5.49 & $5.92,6.14$ & 8.67 & 11.69 \\
f & $>210($ dec. $)$ & $3265(\mathrm{~m}), 3163(\mathrm{w})$ & 5.01 & 5.51 & $6.12,5.88$ & 7.37 & 11.28 \\
g & $>210($ dec. $)$ & $3293(\mathrm{~s}), 3217(\mathrm{w})$ & 5.07 & 5.83 & 5.83 & $/$ & 10.98 \\
\hline
\end{tabular}

When the thymine is introduced $\left(\mathrm{R}^{\prime}=\mathrm{Me}\right)$, the ${ }^{1} \mathrm{H}-\mathrm{NMR}$ spectrum of $\mathbf{1 9 f}$ shows an additional signal at $1.80 \delta$ corresponding to the methyl on the pyrimidine ring. In the parent compound $\mathbf{1 9 g}$ two methyls are found at 2.06 and $1.78 \delta$. 
Despite the variable yields of the products 19a-g obtained, a remarkable selectivity was achieved since in all the cases the pyrimidine rings are linked through the N1 to the cyclopentenyl moiety.

\section{Conclusions}

In summary, an efficient preparation of novel carbocyclic nucleoside analogues was achieved and the scope and the limitations of the methods have been displayed. The starting allylic acetate $\mathbf{7}$ is easily prepared by HDA cycloaddition of nitrosocarbonyl benzene to cyclopentadiene $\mathbf{1}$ followed by the mild reductive cleavage of the $\mathrm{N}-\mathrm{O}$ bond with $\mathrm{Al}(\mathrm{Hg})$ and expedite acetylation with $\mathrm{Ac}_{2} \mathrm{O} / \mathrm{Et}_{3} \mathrm{~N} / \mathrm{DMAP}$ procedure. The palladium(0)-catalyzed addition of both purine, pyrimidine and various heterobases to the allylic acetate allowed to prepare nucleoside compounds with retention of the initial substrate stereochemistry. Further derivatizations are currently developed in order to extend the range of heterobases which can be inserted on the cyclopentenyl ring. The double bond of the nucleosides is also suitable for synthetic elaboration, such as reduction by hydrogenation, oxidation to get the relative diols. ${ }^{10}$ The application of the described protocol to the parent cycloadducts $\mathbf{6 a , b}$ is expect to broad the way to a family of nucleosidic compounds and analogues whose application as agonists or antagonists in selected biological targets is actually pursued.

\section{Experimental Section}

General Procedures. All melting points are uncorrected. Elemental analyses were done on a C. Erba 1106 elemental analyzer. IR spectra (nujol mulls) were recorded on an FT-IR Perkin-Elmer RX-1. ${ }^{1} \mathrm{H}$ - and ${ }^{13} \mathrm{C}-\mathrm{NMR}$ spectra were recorded on a Bruker AVANCE 300 in the specified deuterated solvents. Chemical shifts are expressed in ppm from internal tetramethylsilane $(\delta)$. Column chromatography and tlc: silica gel 60 (0.063-0.200 mm) (Merck); eluant $\mathrm{CHCl}_{3}$. The identification of samples from different experiments was secured by mixed mps and superimposable IR spectra.

Materials. Adenine 9, 6-chloropurine 12, uracils 17a-e, thymines 17f,g, purines 15a,b, benzoimidazole 15c,d and $\mathrm{Pd}\left(\mathrm{PPh}_{3}\right)_{4}$ were purchased from SIGMA-ALDRICH. Cis 4benzoylamino-2-cyclopenten-1-ol 5 was prepared according to the previously reported synthesis. ${ }^{12}$ Cis 4-benzoylamino-2-cyclopenten-1-ol acetate 7 was prepared upon treatment of 5 with $\mathrm{Ac}_{2} \mathrm{O}$ in the presence of $\mathrm{Et}_{3} \mathrm{~N}$ and catalytic DMAP in anhydrous DCM solution. ${ }^{14 \mathrm{a}}$

\section{Synthesis of the adenine derivatives 11a,b}

To an anhydrous DMF solution $(10 \mathrm{~mL})$ of adenine 9 (132 mg, $0.98 \mathrm{mmol}), 33 \mathrm{mg}(1.39 \mathrm{mmol})$ of $\mathrm{NaH}$ (70\% in mineral oil) were added under nitrogen atmosphere. After 3-4h under stirring, a 
DMF solution $(10 \mathrm{~mL})$ of $200 \mathrm{mg}(0.82 \mathrm{mmol})$ of the acetate 7 and $47 \mathrm{mg}(0.04 \mathrm{mmol})$ of $\mathrm{Pd}\left(\mathrm{PPh}_{3}\right)_{4}$ was added and the reaction was continued overnight at r.t. After addition of water, the solution was extracted with DCM and the organic phase dried over anhydrous $\mathrm{Na}_{2} \mathrm{SO}_{4}$. The crude residue, obtained upon evaporation of the solvent, was then submitted to column chromatography. The products 11a,b were isolated in $42 \%$ and $35 \%$ yield, respectively.

11a. (110 mg, 42\%) as white crystals from benzene/petrol ether, m.p. $154-6^{\circ} \mathrm{C}$; [Found $\mathrm{C}, 63.7$; $\mathrm{H}, 5.1 ; \mathrm{N}, 26.3 . \mathrm{C}_{17} \mathrm{H}_{16} \mathrm{~N}_{6} \mathrm{O}(\mathrm{MW}=320.35)$ requires $\mathrm{C}, 63.73 ; \mathrm{H}, 5.04 ; \mathrm{N}, 26.24 \%$ ]; $v_{\max }$ (Nujol) 3310 (br), 3146 (br), 1670 (s) cm ${ }^{-1}$; $\delta_{\mathrm{H}}\left(300 \mathrm{MHz}, \mathrm{CD}_{3} \mathrm{COCD}_{3}\right) 9.19$ (1H, d, J $\left.8 \mathrm{~Hz}, \mathrm{NH}\right), 8.19$ $(1 \mathrm{H}, \mathrm{s}, \mathrm{CH}=\mathrm{N}), 8.08(1 \mathrm{H}, \mathrm{s}, \mathrm{CH}=\mathrm{N}), 7.90(2 \mathrm{H}, \mathrm{m}, \mathrm{Ph}), 7.50(3 \mathrm{H}, \mathrm{m}, \mathrm{Ph}), 6.73\left(2 \mathrm{H}, \mathrm{s}, \mathrm{NH}_{2}\right), 6.20$ $(1 \mathrm{H}, \mathrm{m}, \mathrm{CH}=), 6.02(1 \mathrm{H}, \mathrm{m}, \mathrm{CH}=), 5.69\left(1 \mathrm{H}, \mathrm{m}, \mathrm{CH}-\mathrm{N}_{\text {base }}\right), 5.38(1 \mathrm{H}, \mathrm{m}, \mathrm{CH}-\mathrm{N}), 3.20(1 \mathrm{H}, \mathrm{dt}, J$ 15, $\left.9 \mathrm{~Hz}, \mathrm{CH}_{2}\right), 2.19\left(1 \mathrm{H}, \mathrm{dt}, J 15,2.8 \mathrm{~Hz}, \mathrm{CH}_{2}\right)$; $\delta_{\mathrm{C}}\left(75 \mathrm{MHz}, \mathrm{CD}_{3} \mathrm{COCD}_{3}\right) 166.8$ (s), 157.7 (s), 153.4 (d), 150.4 (s), 141.8 (d), 137.9 (d), 136.6 (d), 132.4 (s), 132.1 (d), 129.7 (d), 128.4 (d), $121.7,60.9(\mathrm{~d}), 55.1(\mathrm{~d}), 38.4(\mathrm{t})$.

11b. (91 mg, 35\%) as white crystals from benzene/petrol ether, m.p. 144- $6{ }^{\circ} \mathrm{C}$; [Found C, 63.6; $\mathrm{H}, 5.0 ; \mathrm{N}, 26.2 . \mathrm{C}_{17} \mathrm{H}_{16} \mathrm{~N}_{6} \mathrm{O}(\mathrm{MW}=320.35)$ requires $\mathrm{C}, 63.73 ; \mathrm{H}, 5.04 ; \mathrm{N}, 26.24 \%$ ]; $v_{\max }(\mathrm{Nujol})$ 3310 (br), 3150 (br), 1675 (m) cm ; $^{-1} \delta_{\mathrm{H}}\left(300 \mathrm{MHz}, \mathrm{CD}_{3} \mathrm{COCD}_{3}\right) 9.93$ (1H, d, J $\left.8 \mathrm{~Hz}, \mathrm{NH}\right), 8.42$ $(1 \mathrm{H}, \mathrm{s}, \mathrm{CH}=\mathrm{N}), 8.03\left(2 \mathrm{H}, \mathrm{s}, \mathrm{NH}_{2}\right), 7.91(2 \mathrm{H}, \mathrm{m}, \mathrm{Ph}), 7.84(1 \mathrm{H}, \mathrm{s}, \mathrm{CH}=\mathrm{N}), 7.55(3 \mathrm{H}, \mathrm{m}, \mathrm{Ph}), 6.20$ $(1 \mathrm{H}, \mathrm{m}, \mathrm{CH}=), 6.05(1 \mathrm{H}, \mathrm{m}, \mathrm{CH}=), 5.77\left(1 \mathrm{H}, \mathrm{d}, J 8 \mathrm{~Hz}, \mathrm{CH}-\mathrm{N}_{\text {base }}\right), 5.28(1 \mathrm{H}, \mathrm{m}, \mathrm{CH}-\mathrm{N}), 3.12$ $\left(1 \mathrm{H}, \mathrm{dt}, J 15,9 \mathrm{~Hz}, \mathrm{CH}_{2}\right), 2.11\left(1 \mathrm{H}, \mathrm{dt}, J 15,2.8 \mathrm{~Hz}, \mathrm{CH}_{2}\right) ; \delta_{\mathrm{C}}\left(75 \mathrm{MHz}, \mathrm{CD}_{3} \mathrm{COCD}_{3}\right) 165.1(\mathrm{~s})$, 155.3 (s), 151.6 (d), 148.7 (s), 142.9 (d), 137.8 (d), 134.7 (d), 131.2 (s), 130.2 (d), 128.4 (d), 127.1 (d), 120.8 (s), 65.0 (d), 53. (d), 36. (t).

\section{Synthesis of the 6-chloropurine derivatives 13a,b}

To an anhydrous DMF solution (10 mL) of 6-chloropurine 12 (152 mg, $0.98 \mathrm{mmol}), 33 \mathrm{mg}$ (1.39 mmol) of $\mathrm{NaH}(70 \%$ in mineral oil) were added under nitrogen atmosphere. After $2 \mathrm{~h}$ under stirring, a DMF solution $(10 \mathrm{~mL})$ of $200 \mathrm{mg}(0.82 \mathrm{mmol})$ of the acetate 7 and $47 \mathrm{mg}(0.04 \mathrm{mmol})$ of $\mathrm{Pd}\left(\mathrm{PPh}_{3}\right)_{4}$ was added and the reaction was continued overnight at r.t. After addition of water, the solution was extracted with DCM and the organic phase dried over anhydrous $\mathrm{Na}_{2} \mathrm{SO}_{4}$. The crude residue, obtained upon evaporation of the solvent, was then submitted to column chromatography. The products 13a,b were isolated in $47 \%$ and $13 \%$ yields, respectively.

13a. (131 mg, 47\%) as white crystals from diisopropyl ether, m.p. $136-140{ }^{\circ} \mathrm{C}$; [Found $\mathrm{C}, 60.1$; $\mathrm{H}, 4.1 ; \mathrm{N}, 20.4 . \mathrm{C}_{17} \mathrm{H}_{14} \mathrm{~N}_{5} \mathrm{OCl}(\mathrm{MW}=339.78)$ requires $\mathrm{C}, 60.09 ; \mathrm{H}, 4.15 ; \mathrm{N}, 20.61 \%$ ]; $v_{\max }$ (Nujol) 3330 (br), $1645(\mathrm{~m}) \mathrm{cm}^{-1}$; $\delta_{\mathrm{H}}\left(300 \mathrm{MHz}, \mathrm{CD}_{3} \mathrm{COCD}_{3}\right) 8.74(1 \mathrm{H}, \mathrm{s}, \mathrm{CH}=\mathrm{N}), 8.59(1 \mathrm{H}, \mathrm{s}$, $\mathrm{CH}=\mathrm{N}), 8.31(1 \mathrm{H}, \mathrm{bs}, \mathrm{NH}), 7.91(2 \mathrm{H}, \mathrm{m}, \mathrm{Ph}), 7.50(3 \mathrm{H}, \mathrm{m}, \mathrm{Ph}), 6.33(1 \mathrm{H}, \mathrm{m}, \mathrm{CH}=), 6.18(1 \mathrm{H}, \mathrm{m}$, $\mathrm{CH}=), 5.89\left(1 \mathrm{H}, \mathrm{m}, \mathrm{CH}-\mathrm{N}_{\text {base }}\right), 5.36(1 \mathrm{H}, \mathrm{m}, \mathrm{CH}-\mathrm{N}), 3.32\left(1 \mathrm{H}, \mathrm{m}, \mathrm{CH}_{2}\right), 2.22\left(1 \mathrm{H}, \mathrm{m}, \mathrm{CH}_{2}\right) ; \delta_{\mathrm{C}}$ (75 MHz, $\left.\mathrm{CD}_{3} \mathrm{COCD}_{3}\right) 167.2$ (s), 153.0 (d), 152.4 (s), 151.2 (d), 147.0 (d), 138.9 (d), 136.2 (s), 132.5 (d), 131.7 (d), 129.7 (d), 129.4 (s), 128.4 (d), 60.9 (d), 55.6 (d), 39.4 (t).

13b. (36 mg, 13\%) as white crystals from diisopropyl ether, m.p. $110-112^{\circ} \mathrm{C}$; [Found $\mathrm{C}, 60.0 ; \mathrm{H}$, 4.0; N, 20.4. $\mathrm{C}_{17} \mathrm{H}_{14} \mathrm{~N}_{5} \mathrm{OCl}(\mathrm{MW}=339.78)$ requires $\mathrm{C}, 60.09 ; \mathrm{H}, 4.15 ; \mathrm{N}, 20.61 \%$ ]; $v_{\max }$ (Nujol) 3272 (br), $1654(\mathrm{~m}) \mathrm{cm}^{-1}$; $\delta_{\mathrm{H}}\left(300 \mathrm{MHz}, \mathrm{CD}_{3} \mathrm{COCD}_{3}\right) 8.77(1 \mathrm{H}, \mathrm{s}, \mathrm{CH}=\mathrm{N}), 8.65(1 \mathrm{H}, \mathrm{s}, \mathrm{CH}=\mathrm{N})$, 
$8.01(1 \mathrm{H}, \mathrm{b}, \mathrm{NH}), 7.83(2 \mathrm{H}, \mathrm{m}, \mathrm{Ph}), 7.52(3 \mathrm{H}, \mathrm{m}, \mathrm{Ph}), 6.43(1 \mathrm{H}, \mathrm{m}, \mathrm{CH}=), 6.36(1 \mathrm{H}, \mathrm{m}, \mathrm{CH}=)$, $6.18\left(1 \mathrm{H}, \mathrm{m}, \mathrm{CH}-\mathrm{N}_{\text {base }}\right), 5.30(1 \mathrm{H}, \mathrm{m}, \mathrm{CH}-\mathrm{N}), 3.38\left(1 \mathrm{H}, \mathrm{m}, \mathrm{CH}_{2}\right), 2.12\left(1 \mathrm{H}, \mathrm{m}, \mathrm{CH}_{2}\right) ; \delta_{\mathrm{C}}(75$ $\left.\mathrm{MHz}, \mathrm{CD}_{3} \mathrm{COCD}_{3}\right) 167.5$ (s), 163.6 (s), 152.8 (d), 149.0 (d), 140.0 (d), 136.0 (s), 133.0 (d), 131.7 (s), 131.2 (d), 129.6 (d), 129.5 (s), 128.5 (d), 62.6 (d), 56.0 (d), 41.9 (t).

\section{Synthesis of the purine derivatives 14a-e. General procedure}

Solutions of chloro-nucleosides 13a (30 mg, $0.09 \mathrm{mmol})$ in $\mathrm{MeOH}(2 \mathrm{~mL})$ were saturated with gaseous amines and kept in a sealed tube at $50{ }^{\circ} \mathrm{C}$ for $24 \mathrm{~h}$. In the case of liquid amines, an excess (50 equiv.) was added to the solutions. The solutions are then cooled and in most cases the products crystallize from the methanolic solutions. Otherwise, concentration of the solutions allows the amino derivatives to crystallize. Table 2 reports the physical constants (solvent of crystallization) and yields of the amino nucleosides 14(a-e).

14a. (29 mg, 99\%) as white crystals from diisopropyl ether/ethanol, m.p. $>210{ }^{\circ} \mathrm{C}$ (dec.); [Found $\mathrm{C}, 64.7 ; \mathrm{H}, 5.2 ; \mathrm{N}, 25.2 . \mathrm{C}_{18} \mathrm{H}_{18} \mathrm{~N}_{6} \mathrm{O}(\mathrm{MW}=334.37)$ requires $\mathrm{C}, 64.65 ; \mathrm{H}, 5.43 ; \mathrm{N}, 25.14 \%$ ]; $v_{\max }$ (Nujol) $3261(\mathrm{~m}), 3222(\mathrm{~m}), 1646(\mathrm{~s}), 1630(\mathrm{~s}) \mathrm{cm}^{-1} ; \delta_{\mathrm{H}}\left(300 \mathrm{MHz}, \mathrm{CD}_{3} \mathrm{COCD}_{3}\right) 9.26(1 \mathrm{H}$, b, NH), $8.27(1 \mathrm{H}, \mathrm{s}, \mathrm{CH}=\mathrm{N}), 8.04(1 \mathrm{H}, \mathrm{s}, \mathrm{CH}=\mathrm{N}), 7.94(2 \mathrm{H}, \mathrm{m}, \mathrm{Ph}), 7.56(3 \mathrm{H}, \mathrm{m}, \mathrm{Ph}), 6.87(1 \mathrm{H}$, $\mathrm{s}, \mathrm{NH}), 6.19(1 \mathrm{H}, \mathrm{m}, \mathrm{CH}=), 6.01(1 \mathrm{H}, \mathrm{m}, \mathrm{CH}=), 5.67\left(1 \mathrm{H}, \mathrm{m}, \mathrm{CH}-\mathrm{N}_{\text {base }}\right), 5.37(1 \mathrm{H}, \mathrm{m}, \mathrm{CH}-\mathrm{N})$, $3.22\left(1 \mathrm{H}, \mathrm{m}, \mathrm{CH}_{2}\right), 3.14\left(3 \mathrm{H}, \mathrm{bs}, \mathrm{CH}_{3}-\mathrm{N}\right), 2.20\left(1 \mathrm{H}, \mathrm{m}, \mathrm{CH}_{2}\right) ; \delta_{\mathrm{C}}\left(75 \mathrm{MHz}, \mathrm{CD}_{3} \mathrm{COCD}_{3}\right) 166.8$ (s), 157.1 (s), 153.4 (d), 141.4 (d), 137.9 (d), 136.7 (s), 136.3 (d), 132.4 (d), 132.2 (d), 129.7 (d), $128.4(\mathrm{~d}), 61.0(\mathrm{~d}), 55.1(\mathrm{~d}), 38.3(\mathrm{t}), 31.0(\mathrm{q})$.

14b. (32 mg, 99\%) as white crystals from diisopropyl ether/ethanol, m.p. 127-130 ${ }^{\circ} \mathrm{C}$; [Found $\mathrm{C}$, 67.1; H, 6.3; N, 22.2. $\mathrm{C}_{21} \mathrm{H}_{24} \mathrm{~N}_{6} \mathrm{O}(\mathrm{MW}=376.45)$ requires $\left.\mathrm{C}, 67.00 ; \mathrm{H}, 6.43 ; \mathrm{N}, 22.33 \%\right]$; $v_{\max }$ (Nujol) 3342 (br), 1647 (s), 1582 (s) cm $\mathrm{cm}^{-1}$; $\delta_{\mathrm{H}}\left(300 \mathrm{MHz}, \mathrm{CD}_{3} \mathrm{COCD}_{3}\right) 9.17(1 \mathrm{H}, \mathrm{d}, \mathrm{J} 7.2 \mathrm{~Hz}$, $\mathrm{NH}), 8.21(1 \mathrm{H}, \mathrm{s}, \mathrm{CH}=\mathrm{N}), 8.08(1 \mathrm{H}, \mathrm{s}, \mathrm{CH}=\mathrm{N}), 7.94(2 \mathrm{H}, \mathrm{m}, \mathrm{Ph}), 7.55(3 \mathrm{H}, \mathrm{m}, \mathrm{Ph}), 6.20(1 \mathrm{H}, \mathrm{m}$, $\mathrm{CH}=), 6.01(1 \mathrm{H}, \mathrm{m}, \mathrm{CH}=), 5.71\left(1 \mathrm{H}, \mathrm{m}, \mathrm{CH}-\mathrm{N}_{\text {base }}\right), 5.37(1 \mathrm{H}, \mathrm{m}, \mathrm{CH}-\mathrm{N}), 3.20\left(2 \mathrm{H}, \mathrm{m}, \mathrm{N}-\mathrm{CH}_{2}\right)$, 2.19 and $2.08\left(1 \mathrm{H}+1 \mathrm{H}, \mathrm{m}, \mathrm{CH}_{2}\right), 1.26\left(3 \mathrm{H}, \mathrm{t}, J 7 \mathrm{~Hz}, \mathrm{CH}_{3}\right) ; \delta_{\mathrm{C}}\left(75 \mathrm{MHz}, \mathrm{CD}_{3} \mathrm{COCD}_{3}\right) 166.9$ (s), 155.0 (s), 152.8 (d), 151.2 (s), 140.7 (d), 136.9 (d), 136.7 (s), 134.0 (s), 132.4 (d), 132.2 (d), 129.7 (d), 128.4 (d), 121.7 (s), 60.8 (d), 55.2 (d), 43.9 (t), 43.1 (t), 38.4 (t), 14.2 (q), 11.9 (q).

14c. (31 mg, 98\%) as white crystals from diisopropyl ether/ethanol, m.p. 193-195 ${ }^{\circ} \mathrm{C}$; [Found C, 66.7; H, 5.6; N, 23.2. $\mathrm{C}_{20} \mathrm{H}_{20} \mathrm{~N}_{6} \mathrm{O}(\mathrm{MW}=360.41)$ requires $\mathrm{C}, 66.65 ; \mathrm{H}, 5.59 ; \mathrm{N}, 23.32 \%$; $v_{\max }$ (Nujol) $3214(\mathrm{~m}), 1645$ (s), $1620(\mathrm{~s}) \mathrm{cm}^{-1}$; $\delta_{\mathrm{H}}\left(300 \mathrm{MHz}, \mathrm{CD}_{3} \mathrm{COCD}_{3}\right) 9.22(1 \mathrm{H}, \mathrm{b}, \mathrm{NH}), 8.29$ $(1 \mathrm{H}, \mathrm{s}, \mathrm{CH}=\mathrm{N}), 8.05(1 \mathrm{H}, \mathrm{s}, \mathrm{CH}=\mathrm{N}), 7.94(2 \mathrm{H}, \mathrm{m}, \mathrm{Ph}), 7.55(3 \mathrm{H}, \mathrm{m}, \mathrm{Ph}), 6.80(1 \mathrm{H}, \mathrm{b}, \mathrm{NH}), 6.20$ $(1 \mathrm{H}, \mathrm{m}, \mathrm{CH}=), 6.00(1 \mathrm{H}, \mathrm{m}, \mathrm{CH}=), 5.68\left(1 \mathrm{H}, \mathrm{m}, \mathrm{CH}-\mathrm{N}_{\text {base }}\right), 5.38(1 \mathrm{H}, \mathrm{m}, \mathrm{CH}-\mathrm{N}), 3.19(2 \mathrm{H}, \mathrm{m}$, $\left.\mathrm{CH}_{2}\right), 2.17(1 \mathrm{H}, \mathrm{m}, \mathrm{N}-\mathrm{CH}), 0.82\left(2 \mathrm{H}, \mathrm{m}, \mathrm{CH}_{2}\right), 0.70\left(2 \mathrm{H}, \mathrm{m}, \mathrm{CH}_{2}\right) ; \delta_{\mathrm{C}}\left(75 \mathrm{MHz}, \mathrm{CD}_{3} \mathrm{COCD}_{3}\right)$ 166.8 (s), 157.4 (s), 153.3 (d), 141.5 (d), 137.9 (d), 136.7 (s), 136.2 (s), 133.4 (s), 132.4 (d), 132.1 (d), 129.7 (d), 128.4 (d), 122.1 (s), 60.9 (d), 55.1 (d), 38.4 (t), 32.4 (d), 25.1 (t), 7.8 (t).

14d. (36 mg, 97\%) as white crystals from diisopropyl ether/ethanol, m.p. 202-205 ${ }^{\circ} \mathrm{C}$; [Found C, 70.3; H, 5.5; N, 20.3. $\mathrm{C}_{20} \mathrm{H}_{20} \mathrm{~N}_{6} \mathrm{O}(\mathrm{MW}=410.46)$ requires $\mathrm{C}, 70.22 ; \mathrm{H}, 5.40 ; \mathrm{N}, 20.48 \%$; $v_{\max }$ (Nujol) 3326 (br), 3266 (br), 1628 (vs) cm ${ }^{-1}$; $\delta_{\mathrm{H}}\left(300 \mathrm{MHz}, \mathrm{CD}_{3} \mathrm{COCD}_{3}\right) 9.22(1 \mathrm{H}, \mathrm{b}, \mathrm{NH}), 8.26$ $(1 \mathrm{H}, \mathrm{s}, \mathrm{CH}=\mathrm{N}), 8.08(1 \mathrm{H}, \mathrm{s}, \mathrm{CH}=\mathrm{N}), 7.93(2 \mathrm{H}, \mathrm{m}, \mathrm{Ph}), 7.2-7.6(9 \mathrm{H}, \mathrm{m}, \mathrm{Ph}$ and $\mathrm{NH}), 6.20(1 \mathrm{H}, \mathrm{m}$, 
$\mathrm{CH}=), 6.01(1 \mathrm{H}, \mathrm{m}, \mathrm{CH}=), 5.69\left(1 \mathrm{H}, \mathrm{m}, \mathrm{CH}-\mathrm{N}_{\text {base }}\right), 5.38(1 \mathrm{H}, \mathrm{m}, \mathrm{CH}-\mathrm{N}), 4.83\left(2 \mathrm{H}, \mathrm{m}, \mathrm{CH}_{2}\right), 3.20$ $\left(1 \mathrm{H}, \mathrm{m}, \mathrm{CH}_{2}\right), 2.18\left(1 \mathrm{H}, \mathrm{m}, \mathrm{CH}_{2}\right) ; \delta_{\mathrm{C}}\left(75 \mathrm{MHz}, \mathrm{CD}_{3} \mathrm{COCD}_{3}\right) 166.7$ (s), 152.9 (d), 147.2 (d), 141.2 (s), 137.5 (d), 132.0 (d), 131.7 (d), 129.4 (s), 129.3 (d), 129.1 (d), 128.2 (d), 127.9 (d), $127.6(d), 121.1(\mathrm{~s}), 60.5(\mathrm{~d}), 54.6(\mathrm{~d}), 37.9(\mathrm{t})$.

\section{Synthesis of compounds 16(a-d)}

To an anhydrous DMF solution $(10 \mathrm{~mL})$ of the heterobases $15(0.98 \mathrm{mmol}), 33 \mathrm{mg}(1.39 \mathrm{mmol})$ of $\mathrm{NaH}(70 \%$ in mineral oil) were added under nitrogen atmosphere. After $2 \mathrm{~h}$ under stirring, a DMF solution $(10 \mathrm{~mL})$ of $200 \mathrm{mg}(0.82 \mathrm{mmol})$ of the acetate 7 and $47 \mathrm{mg}(0.04 \mathrm{mmol})$ of $\mathrm{Pd}\left(\mathrm{PPh}_{3}\right)_{4}$ was added and the reaction was continued overnight at r.t. After addition of water, the solution was extracted with DCM and the organic phase dried over anhydrous $\mathrm{Na}_{2} \mathrm{SO}_{4}$. The crude residue, obtained upon evaporation of the solvent, was then submitted to column chromatography. The products $\mathbf{1 6 ( a - d )}$ were isolated fully characterized.

16a. (181 mg, 60\%) as white crystals from diisopropyl ether, m.p. $>210{ }^{\circ} \mathrm{C}$ (dec.); [Found $\mathrm{C}$, 58.6; H, 4.7; N, 22.7. $\mathrm{C}_{18} \mathrm{H}_{17} \mathrm{~N}_{6} \mathrm{OCl}(\mathrm{MW}=368.83)$ requires $\mathrm{C}, 58.62 ; \mathrm{H}, 4.65 ; \mathrm{N}, 22.79 \%$; $v_{\max }$ (Nujol) 3436 (br), 3276 (s), 1634 (s) cm c $^{-1} \delta_{\mathrm{H}}(300 \mathrm{MHz}, \mathrm{DMSO}) 8.19$ (1H, d, J $7.7 \mathrm{~Hz}, \mathrm{NH}-$ CO), 7.81 (1H, d, J $4.5 \mathrm{~Hz}, \mathrm{NH}-\mathrm{Me}), 7.75(1 \mathrm{H}, \mathrm{s}, \mathrm{CH}=\mathrm{N}), 7.39$ (2H, m, Ph), 7.04 (3H, m, Ph), $5.73(1 \mathrm{H}, \mathrm{m}, \mathrm{CH}=), 5.62(1 \mathrm{H}, \mathrm{m}, \mathrm{CH}=), 5.08\left(1 \mathrm{H}, \mathrm{m}, \mathrm{CH}-\mathrm{N}_{\text {base }}\right), 4.68(1 \mathrm{H}, \mathrm{m}, \mathrm{CH}-\mathrm{N}), 2.90(3 \mathrm{H}$, s, $\left.\mathrm{CH}_{3}\right), 2.65\left(1 \mathrm{H}, \mathrm{m}, \mathrm{CH}_{2}\right), 1.43\left(1 \mathrm{H}, \mathrm{m}, \mathrm{CH}_{2}\right) ; \delta_{\mathrm{C}}(75 \mathrm{MHz}, \mathrm{DMSO}) 165.9$ (s), 155.5 (s), 153.2 (s), 149.1 (s), 139.4 (d), 137.0 (d), 134.3 (d), 131.3 (d), 131.0 (d), 128.2 (d), 127.3 (d), 118.3 (s), 57.5 (d), 53.9 (d), 38.9 (t), 27.2 (q).

16b (or 16b'). (97 mg, 37\%) as white crystals from diisopropyl ether, m.p. $>215{ }^{\circ} \mathrm{C}$ (dec.); [Found $\mathrm{C}, 63.6 ; \mathrm{H}, 4.7 ; \mathrm{N}, 21.7 . \mathrm{C}_{17} \mathrm{H}_{15} \mathrm{~N}_{5} \mathrm{O}_{2}(\mathrm{MW}=321.33)$ requires $\mathrm{C}, 63.54 ; \mathrm{H}, 4.70 ; \mathrm{N}$, $21.80 \%$ ]; $v_{\max }$ (Nujol) 3277 (s), 1697 (s), 1683 (s), 1632 (s) $\mathrm{cm}^{-1} ; \delta_{\mathrm{H}}(300 \mathrm{MHz}, \mathrm{DMSO}) 12.34$ $(1 \mathrm{H}, \mathrm{s}, \mathrm{OH}), 8.84(1 \mathrm{H}, \mathrm{d}, \mathrm{J} 7.6 \mathrm{~Hz}, \mathrm{NH}-\mathrm{CO}), 8.26(1 \mathrm{H}, \mathrm{s}, \mathrm{CH}=\mathrm{N}), 8.22(1 \mathrm{H}, \mathrm{s}, \mathrm{CH}=\mathrm{N}), 8.00(2 \mathrm{H}$, $\mathrm{m}, \mathrm{Ph}), 7.58(3 \mathrm{H}, \mathrm{m}, \mathrm{Ph}), 6.22(1 \mathrm{H}, \mathrm{m}, \mathrm{CH}=), 6.10(1 \mathrm{H}, \mathrm{m}, \mathrm{CH}=), 5.92\left(1 \mathrm{H}, \mathrm{m}, \mathrm{CH}-\mathrm{N}_{\text {base }}\right), 5.23$ $(1 \mathrm{H}, \mathrm{m}, \mathrm{CH}-\mathrm{N}), 3.00\left(1 \mathrm{H}, \mathrm{m}, \mathrm{CH}_{2}\right), 2.25\left(1 \mathrm{H}, \mathrm{m}, \mathrm{CH}_{2}\right) ; \delta_{\mathrm{C}}(75 \mathrm{MHz}, \mathrm{DMSO}) 165.6$ (s), 157.3 (s), 151.5 (s), 148.1 (d), 135.9 (d), 134.6 (d), 134.1 (s), 131.8 (d), 131.2 (d), 128.3 (d), 127.3 (d), $105.9(\mathrm{~s}), 60.3(\mathrm{~d}), 53.6(\mathrm{~d}), 37.7(\mathrm{t})$.

16b' (or 16b). (32 mg, 12\%) as white crystals from diisopropyl ether, m.p. $>215{ }^{\circ} \mathrm{C}$ (dec.); [Found $\mathrm{C}, 63.5 ; \mathrm{H}, 4.6 ; \mathrm{N}, 21.8 . \mathrm{C}_{17} \mathrm{H}_{15} \mathrm{~N}_{5} \mathrm{O}_{2}(\mathrm{MW}=321.33)$ requires $\mathrm{C}, 63.54 ; \mathrm{H}, 4.70 ; \mathrm{N}$, $21.80 \%$ ]; $v_{\max }$ (Nujol) 3250 (br), $1688(\mathrm{~s}), 1640(\mathrm{~m}) \mathrm{cm}^{-1} ; \delta_{\mathrm{H}}(300 \mathrm{MHz}, \mathrm{DMSO}) 11.75(1 \mathrm{H}, \mathrm{s}$, $\mathrm{OH}), 8.76(1 \mathrm{H}, \mathrm{d}, J 7.9 \mathrm{~Hz}, \mathrm{NH}-\mathrm{CO}), 8.61(1 \mathrm{H}, \mathrm{s}, \mathrm{CH}=\mathrm{N}), 7.96(1 \mathrm{H}, \mathrm{s}, \mathrm{CH}=\mathrm{N}), 7.89(2 \mathrm{H}, \mathrm{m}$, $\mathrm{Ph}), 7.47(3 \mathrm{H}, \mathrm{m}, \mathrm{Ph}), 6.16(1 \mathrm{H}, \mathrm{m}, \mathrm{CH}=), 6.09(1 \mathrm{H}, \mathrm{m}, \mathrm{CH}=), 5.58\left(1 \mathrm{H}, \mathrm{m}, \mathrm{CH}-\mathrm{N}_{\text {base }}\right), 5.13(1 \mathrm{H}$, m, CH-N), $3.02\left(1 \mathrm{H}, \mathrm{m}, \mathrm{CH}_{2}\right), 2.03\left(1 \mathrm{H}, \mathrm{m}, \mathrm{CH}_{2}\right) ; \delta_{\mathrm{C}}(75 \mathrm{MHz}, \mathrm{DMSO}) 165.6$ (s), 158.7 (s), 158.5 (s), 146.9 (d), 137.0 (d), 134.2 (s), 131.3 (d), 131.2 (d), 128.3 (d), 127.5 (d), 127.3 (d), $107.0(\mathrm{~s}), 66.5(\mathrm{~d}), 53.6(\mathrm{~d}), 38.6(\mathrm{t})$.

16c. (26 mg, 10\%) as white crystals from diisopropyl ether/ethanol, m.p. 110-112 ${ }^{\circ} \mathrm{C}$; [Found C, 75.6; H, 6.1; N, 13.3. $\mathrm{C}_{20} \mathrm{H}_{19} \mathrm{~N}_{3} \mathrm{O}(\mathrm{MW}=317.38)$ requires $\mathrm{C}, 75.68 ; \mathrm{H}, 6.03 ; \mathrm{N}, 13.24 \%$; $v_{\max }$ (Nujol) 3196 (br), $1652(\mathrm{~m}) \mathrm{cm}^{-1}$; $\delta_{\mathrm{H}}\left(300 \mathrm{MHz}, \mathrm{CD}_{3} \mathrm{COCD}_{3}\right) 8.06(1 \mathrm{H}, \mathrm{b}, \mathrm{NH}), 8.05(1 \mathrm{H}, \mathrm{d}, J$ 
6.1 Hz, $\left.\mathrm{CH}_{\text {benzoimid. }}\right), 7.90(2 \mathrm{H}, \mathrm{m}, \mathrm{Ph}), 7.50\left[\mathrm{~m}, 1 \mathrm{H}(\mathrm{CH}=\mathrm{N}), 3 \mathrm{H}(\mathrm{Ph}), 1 \mathrm{H}\left(\mathrm{CH}_{\text {benzoimid }}\right)\right], 7.07$ $\left(1 \mathrm{H}, \mathrm{m}, \mathrm{CH}_{\text {benzoimid }}\right), 6.32(1 \mathrm{H}, \mathrm{m}, \mathrm{CH}=), 6.22(1 \mathrm{H}, \mathrm{m}, \mathrm{CH}=), 5.67\left(1 \mathrm{H}, \mathrm{m}, \mathrm{CH}-\mathrm{N}_{\text {base }}\right), 5.29(1 \mathrm{H}$, $\mathrm{m}, \mathrm{CH}-\mathrm{N}), 3.26\left(1 \mathrm{H}, \mathrm{m}, \mathrm{CH}_{2}\right), 2.45\left(3 \mathrm{H}, \mathrm{m}, \mathrm{CH}_{3}\right), 2.02\left(1 \mathrm{H}, \mathrm{m}, \mathrm{CH}_{2}\right) ; \delta_{\mathrm{C}}\left(75 \mathrm{MHz}, \mathrm{CD}_{3} \mathrm{COCD}_{3}\right)$ 167.5 (s), 142.5 (s), 138.0 (d), 136.4 (d), 132.7 (s), 132.4 (d), 129.5 (s), 128.5 (d), 124.9 (d), 124. (d)0, 120.7 (d), 111.5 (s), 60.5 (d), 55.8 (d), 40.5 (t), 21.9 (q).

16d. (188 mg, 66\%) as white crystals from diisopropyl ether/ethanol, m.p. 179-181 ${ }^{\circ} \mathrm{C}$; [Found $\mathrm{C}, 65.5 ; \mathrm{H}, 4.7 ; \mathrm{N}, 16.2 . \mathrm{C}_{19} \mathrm{H}_{16} \mathrm{~N}_{4} \mathrm{O}_{3}(\mathrm{MW}=348.35)$ requires $\mathrm{C}, 65.51 ; \mathrm{H}, 4.63 ; \mathrm{N}, 16.08 \%$; $v_{\max }$ (Nujol) 3279 (br), $1630(\mathrm{~s}), 1377(\mathrm{~m}) \mathrm{cm}^{-1} ; \delta_{\mathrm{H}}\left(300 \mathrm{MHz}, \mathrm{CD}_{3} \mathrm{COCD}_{3}\right) 8.68(1 \mathrm{H}, \mathrm{s}, \mathrm{CH}=\mathrm{N})$, $8.51(1 \mathrm{H}, \mathrm{s}, \mathrm{CH}=\mathrm{N}), 8.17(1 \mathrm{H}, \mathrm{d}, J 7.9 \mathrm{~Hz}, \mathrm{NH}-\mathrm{CO}), 7.89(2 \mathrm{H}, \mathrm{m}, \mathrm{Ph}), 7.47$ (3H, m, Ph), 6.41 $(1 \mathrm{H}, \mathrm{m}, \mathrm{CH}=), 6.30(1 \mathrm{H}, \mathrm{m}, \mathrm{CH}=), 5.94\left(1 \mathrm{H}, \mathrm{m}, \mathrm{CH}-\mathrm{N}_{\text {base }}\right), 5.32(1 \mathrm{H}, \mathrm{m}, \mathrm{CH}-\mathrm{N}), 3.40(1 \mathrm{H}, \mathrm{m}$, $\left.\mathrm{CH}_{2}\right), 2.12\left(1 \mathrm{H}, \mathrm{m}, \mathrm{CH}_{2}\right) ; \delta_{\mathrm{C}}\left(75 \mathrm{MHz}, \mathrm{CD}_{3} \mathrm{COCD}_{3}\right) 167.6(\mathrm{~s}), 150.0$ (s), 148.3, 144.7 (s), 139.0 (d), 136.0 (d), 132.4 (s), 132.0 (d), 129.5 (d), 128.5 (d), 121.2 (d), 118.5 (d), 109.0 (s), 61.3 (d), $55.9(\mathrm{~d}), 40.5(\mathrm{t})$.

\section{Synthesis of the pyrimidine derivatives 19a-g}

A clear solution of pyrimidines $17 \mathbf{a}-\mathbf{g}(0.87 \mathrm{mmol})$ in anhydrous DMF $(10 \mathrm{~mL})$ was made by heating at $65{ }^{\circ} \mathrm{C}$ for 10 minutes. To the colled solution, $1.2 \mathrm{mmol}$ of $\mathrm{NaH}(70 \%$ in mineral oil) were added under nitrogen atmosphere and heating is carried on for 30 minutes under stirring. The solution was then colled down to room temperature and a DMF solution $(10 \mathrm{~mL})$ of 0.87 mmol of the acetate 7 and $0.43 \mathrm{mmol}$ of $\mathrm{Pd}\left(\mathrm{PPh}_{3}\right)_{4}$ was added. The reaction was continued overnight at $65{ }^{\circ} \mathrm{C}$. After filtration and addition of water, the solution was extracted with DCM and the organic phase dried over anhydrous $\mathrm{Na}_{2} \mathrm{SO}_{4}$. The crude residue, obtained upon evaporation of the solvent, was then submitted to column chromatography. The products 19a-g were isolated in the reported yields.

19a. (166 mg, 64\%) as white crystals from benzene/petrol ether, m.p. 217-220 ${ }^{\circ} \mathrm{C}$; [Found C, 64.7; H, 5.1; N, 14.3. $\mathrm{C}_{16} \mathrm{H}_{15} \mathrm{~N}_{3} \mathrm{O}_{3}(\mathrm{MW}=297.30)$ requires $\mathrm{C}, 64.63 ; \mathrm{H}, 5.09 ; \mathrm{N}, 14.14 \%$ ]; $v_{\max }$ (Nujol) 3425 (br), 3223 (br), $1683(\mathrm{~m}) \mathrm{cm}^{-1}$; $\delta_{\mathrm{H}}$ (300 MHz, DMSO) 11.29 (1H, s, CONHCO), $8.63(1 \mathrm{H}, \mathrm{d}, J 7.9 \mathrm{~Hz}, \mathrm{NH}), 7.84(2 \mathrm{H}, \mathrm{m}, \mathrm{Ph}), 7.56(1 \mathrm{H}, \mathrm{dd}, J$ 8, $1.5 \mathrm{~Hz}, \mathrm{~N}-\mathrm{CH}=), 7.48(3 \mathrm{H}, \mathrm{m}$, $\mathrm{Ph}), 6.11(1 \mathrm{H}, \mathrm{m}, \mathrm{CH}=), 5.87(1 \mathrm{H}, \mathrm{m}, \mathrm{CH}=), 5.87(1 \mathrm{H}, \mathrm{dd}, J 8,1.5 \mathrm{~Hz}, \mathrm{CO}-\mathrm{CH}=), 5.51(1 \mathrm{H}, \mathrm{m}$, CH-N base), $5.00(1 \mathrm{H}, \mathrm{m}, \mathrm{CH}-\mathrm{N}), 2.89\left(1 \mathrm{H}, \mathrm{dt}, J 14,7 \mathrm{~Hz}, \mathrm{CH}_{2}\right), 1.58\left(1 \mathrm{H}, \mathrm{dt}, J 14,7 \mathrm{~Hz}, \mathrm{CH}_{2}\right)$; $\delta_{\mathrm{C}}(75 \mathrm{MHz}, \mathrm{DMSO}) 165.8$ (s), 163.3 (s), 150.9 (s), 141.9 (d), 137.7 (d), 134.4 (s), 131.3 (d), 131.0 (d), 128.3 (d), 127.3 (d), 101.7 (d), 58.7 (d), 53.7, 37.5 (t).

19b. (107 mg, 39\%) as white crystals from benzene/n-hexane, m.p. 78-80 ${ }^{\circ} \mathrm{C}$; [Found $\mathrm{C}, 60.9 ; \mathrm{H}$, 4.5; $\mathrm{N}, 13.3 . \mathrm{C}_{16} \mathrm{H}_{14} \mathrm{~N}_{3} \mathrm{O}_{3} \mathrm{~F}(\mathrm{MW}=315.31)$ requires $\mathrm{C}, 60.95 ; \mathrm{H}, 4.48 ; \mathrm{N}, 13.33 \%$ ]; $v_{\max }(\mathrm{Nujol})$ 3370 (br), 3185 (br), 1709 (s) cm c $^{-1} \delta_{\mathrm{H}}(300 \mathrm{MHz}, \mathrm{DMSO}) 11.12$ (1H, s, CONHCO), 8.63 (1H, d, $J 8.1 \mathrm{~Hz}, \mathrm{NH}), 8.32(1 \mathrm{H}, \mathrm{d}, J 8 \mathrm{~Hz}, \mathrm{~N}-\mathrm{CH}=), 7.82(2 \mathrm{H}, \mathrm{m}, \mathrm{Ph}), 7.50(3 \mathrm{H}, \mathrm{m}, \mathrm{Ph}), 6.11(1 \mathrm{H}, \mathrm{m}$, $\mathrm{CH}=), 5.87(1 \mathrm{H}, \mathrm{m}, \mathrm{CO}-\mathrm{CH}=), 5.75\left(1 \mathrm{H}, \mathrm{m}, \mathrm{CH}-\mathrm{N}_{\text {base }}\right), 5.04(1 \mathrm{H}, \mathrm{m}, \mathrm{CH}-\mathrm{N}), 2.89(1 \mathrm{H}, \mathrm{dt}, J 13$, $5 \mathrm{~Hz}, \mathrm{CH}_{2}$ ), $2.03\left(1 \mathrm{H}, \mathrm{dt}, J\right.$ 13, $5 \mathrm{~Hz}, \mathrm{CH}_{2}$ ); $\delta_{\mathrm{C}}$ (75 MHz, DMSO) 165.8 (s), 157.6 (s), 149.9 (s), 141.6 (d), 138.5 (d), 134.4 (s), 131.3 (d), 130.9 (d), 127.2 (d), 127.0 (d), 79.2 (d), 59.1 (d), 53.6 (d), $37.2(\mathrm{t})$. 
19c. (138 mg, 48\%) as white crystals from benzene/n-hexane, m.p. $147-150{ }^{\circ} \mathrm{C}$; [Found $\mathrm{C}, 57.9$; $\mathrm{H}, 4.3 ; \mathrm{N}, 12.7 . \mathrm{C}_{16} \mathrm{H}_{14} \mathrm{~N}_{3} \mathrm{O}_{3} \mathrm{Cl}(\mathrm{MW}=331.76)$ requires $\left.\mathrm{C}, 57.93 ; \mathrm{H}, 4.25 ; \mathrm{N}, 12.67 \%\right] ; v_{\max }$ (Nujol) 3310 (br), 3167 (br), 1696 (s) cm ${ }^{-1}$; $\delta_{\mathrm{H}}(300 \mathrm{MHz}, \mathrm{DMSO}) 11.85$ (1H, s, CONHCO), $8.63(1 \mathrm{H}, \mathrm{d}, J 8 \mathrm{~Hz}, \mathrm{NH}), 8.67(1 \mathrm{H}, \mathrm{d}, J 8 \mathrm{~Hz}, \mathrm{~N}-\mathrm{CH}=), 7.85(1 \mathrm{H}, \mathrm{s}, \mathrm{N}-\mathrm{CH}=), 7.84(2 \mathrm{H}, \mathrm{m}, \mathrm{Ph})$, $7.50(3 \mathrm{H}, \mathrm{m}, \mathrm{Ph}), 6.13(1 \mathrm{H}, \mathrm{m}, \mathrm{CH}=), 5.91(1 \mathrm{H}, \mathrm{m}, \mathrm{CH}=), 5.52\left(1 \mathrm{H}, \mathrm{m}, \mathrm{CH}-\mathrm{N}_{\text {base }}\right), 5.03(1 \mathrm{H}, \mathrm{m}$, CH-N), $2.89\left(1 \mathrm{H}, \mathrm{dt}, J 14,6 \mathrm{~Hz}, \mathrm{CH}_{2}\right), 1.60\left(1 \mathrm{H}, \mathrm{dt}, J 14,6 \mathrm{~Hz}, \mathrm{CH}_{2}\right) ; \delta_{\mathrm{C}}(75 \mathrm{MHz}, \mathrm{DMSO})$ 166.1 (s), 159.5 (s), 150.4 (s), 139.6 (d), 138.6 (d), 134.7 (s), 131.7 (d), 131.2 (d), 128.7 (d), 127.6 (d), 107.4 (d), 59.7 (d), 54.0 (d), 37.9 (t).

19d. $\left(98 \mathrm{mg}, 30 \%\right.$ ) as white crystals from benzene/n-hexane, m.p. $230{ }^{\circ} \mathrm{C}$ (dec.); [Found C, 51.1; $\mathrm{H}, 3.8 ; \mathrm{N}, 11.1 . \mathrm{C}_{16} \mathrm{H}_{14} \mathrm{~N}_{3} \mathrm{O}_{3} \mathrm{Br}(\mathrm{MW}=376.21)$ requires $\left.\mathrm{C}, 51.08 ; \mathrm{H}, 3.75 ; \mathrm{N}, 11.17 \%\right] ; v_{\max }$ (Nujol) 3250 (br), 3150 (br), 1690 (s) cm ${ }^{-1}$; $\delta_{\mathrm{H}}(300 \mathrm{MHz}, \mathrm{DMSO}) 11.84(1 \mathrm{H}, \mathrm{s}, \mathrm{CONHCO}$ ), $8.63(1 \mathrm{H}, \mathrm{d}, J 8 \mathrm{~Hz}, \mathrm{NH}), 7.89(1 \mathrm{H}, \mathrm{s}, \mathrm{N}-\mathrm{CH}=), 7.85(2 \mathrm{H}, \mathrm{m}, \mathrm{Ph}), 7.51(3 \mathrm{H}, \mathrm{m}, \mathrm{Ph}), 6.15(1 \mathrm{H}, \mathrm{m}$, $\mathrm{CH}=), 5.91(1 \mathrm{H}, \mathrm{m}, \mathrm{CH}=), 5.51\left(1 \mathrm{H}, \mathrm{m}, \mathrm{CH}-\mathrm{N}_{\text {base }}\right), 5.02(1 \mathrm{H}, \mathrm{m}, \mathrm{CH}-\mathrm{N}), 1.93(1 \mathrm{H}, \mathrm{dt}, J 14,6$ $\mathrm{Hz}, \mathrm{CH}_{2}$ ), $1.62\left(1 \mathrm{H}, \mathrm{dt}, J\right.$ 14, $\left.6 \mathrm{~Hz}, \mathrm{CH}_{2}\right)$; $\delta_{\mathrm{C}}(75 \mathrm{MHz}, \mathrm{DMSO}) 165.8$ (s), 159.3 (s), 150.3 (s), 141.6 (d), 138.2 (d), 134.4 (s), 131.3 (d), 130.8 (d), 128.3 (d), 127.3 (d), 95.6 (d), 59.4 (d), 53.6 (d), $37.6(\mathrm{t})$.

19e. $(59 \mathrm{mg}, 16 \%)$ as white crystals from benzene/n-hexane, m.p. $194{ }^{\circ} \mathrm{C}(\mathrm{dec}$.); [Found $\mathrm{C}, 45.4$; $\mathrm{H}, 3.4 ; \mathrm{N}, 10.0 . \mathrm{C}_{16} \mathrm{H}_{14} \mathrm{~N}_{3} \mathrm{O}_{3} \mathrm{I}(\mathrm{MW}=423.21)$ requires $\mathrm{C}, 45.41 ; \mathrm{H}, 3.33 ; \mathrm{N}, 9.93 \%$ ]; $v_{\max }$ (Nujol) 3310 (br), 3167 (br), 1703 (s) cm ${ }^{-1}$; $\delta_{\mathrm{H}}(300 \mathrm{MHz}, \mathrm{DMSO}) 11.69(1 \mathrm{H}, \mathrm{s}, \mathrm{CONHCO}), 8.65(1 \mathrm{H}, \mathrm{d}$, $J 8 \mathrm{~Hz}, \mathrm{NH}), 7.88(1 \mathrm{H}, \mathrm{s}, \mathrm{N}-\mathrm{CH}=), 7.86(2 \mathrm{H}, \mathrm{m}, \mathrm{Ph}), 7.51(3 \mathrm{H}, \mathrm{m}, \mathrm{Ph}), 6.14(1 \mathrm{H}, \mathrm{m}, \mathrm{CH}=), 5.92$ $(1 \mathrm{H}, \mathrm{m}, \mathrm{CH}=), 5.49\left(1 \mathrm{H}, \mathrm{m}, \mathrm{CH}-\mathrm{N}_{\text {base }}\right), 5.00(1 \mathrm{H}, \mathrm{m}, \mathrm{CH}-\mathrm{N}), 2.86\left(1 \mathrm{H}, \mathrm{dt}, J 14,6 \mathrm{~Hz}, \mathrm{CH}_{2}\right), 1.51$ (1H, dt, J 14, $6 \mathrm{~Hz}, \mathrm{CH}_{2}$ ); $\delta_{\mathrm{C}}(75 \mathrm{MHz}, \mathrm{DMSO}) 165.8$ (s), 160.7 (s), 150.6 (s), 146.1 (d), 138.2 (d), 134.4 (s), 131.3 (d), 130.9 (d), 128.3 (d), 127.3 (d), 69.4 (d), 59.2 (d), 53.6 (d), 37.7 (t).

19f. (111 mg, 41\%) as white crystals from diisopropyl ether/ethanol, m.p. $>210{ }^{\circ} \mathrm{C}$ (dec.); [Found $\mathrm{C}, 65.5 ; \mathrm{H}, 5.4 ; \mathrm{N}, 13.5 . \mathrm{C}_{17} \mathrm{H}_{17} \mathrm{~N}_{3} \mathrm{O}_{3}(\mathrm{MW}=311.33)$ requires $\mathrm{C}, 65.58 ; \mathrm{H}, 5.50 ; \mathrm{N}$, $13.50 \%$ ]; $v_{\max }$ (Nujol) 3265 (m), $3163(\mathrm{w}), 1697$ (s), $1676(\mathrm{~m}), 1646(\mathrm{~s}) \mathrm{cm}^{-1} ; \delta_{\mathrm{H}}(300 \mathrm{MHz}$, DMSO) $11.28(1 \mathrm{H}, \mathrm{s}, \mathrm{CONHCO}), 8.62(1 \mathrm{H}, \mathrm{d}, J 7.6 \mathrm{~Hz}, \mathrm{NH}), 7.84(2 \mathrm{H}, \mathrm{m}, \mathrm{Ph}), 7.52(3 \mathrm{H}, \mathrm{m}$, $\mathrm{Ph}), 7.37\left(1 \mathrm{H}, \mathrm{s}, \mathrm{CH}=\right.$ thym $\left._{\text {. }}\right), 6.12(1 \mathrm{H}, \mathrm{m}, \mathrm{CH}=), 5.88(1 \mathrm{H}, \mathrm{m}, \mathrm{CH}=), 5.51\left(1 \mathrm{H}, \mathrm{m}, \mathrm{CH}-\mathrm{N}_{\text {base }}\right), 5.01$ $(1 \mathrm{H}, \mathrm{m}, \mathrm{CH}-\mathrm{N}), 2.87\left(1 \mathrm{H}, \mathrm{m}, \mathrm{CH}_{2}\right), 1.80\left(3 \mathrm{H}, \mathrm{s}, \mathrm{CH}_{3}\right), 1.57\left(1 \mathrm{H}, \mathrm{m}, \mathrm{CH}_{2}\right) ; \delta_{\mathrm{C}}(75 \mathrm{MHz}, \mathrm{DMSO})$ 165.9 (s), 163.8 (s), 150.9 (s), 137.5 (d), 137.4 (d), 134.4 (s), 131.3 (d), 128.3 (d), 127.3 (d), 109.3 (d), 58.4 (d), 53.7 (d), 37.5 (t), 12.3 (q).

19g. (136 mg, 48\%) as white crystals from benzene/n-hexane, m.p. $>210{ }^{\circ} \mathrm{C}$ (dec.); [Found $\mathrm{C}$, 66.4; $\mathrm{H}, 5.8 ; \mathrm{N}, 13.0 . \mathrm{C}_{17} \mathrm{H}_{19} \mathrm{~N}_{3} \mathrm{O}_{3}(\mathrm{MW}=325.36)$ requires $\left.\mathrm{C}, 66.44 ; \mathrm{H}, 5.89 ; \mathrm{N}, 12.92 \%\right] ; v_{\max }$ (Nujol) 3293 (s), $3217(\mathrm{w}), 1712(\mathrm{~m}), 1685(\mathrm{w}), 1629(\mathrm{~s}) \mathrm{cm}^{-1}$; $\delta_{\mathrm{H}}(300 \mathrm{MHz}, \mathrm{DMSO}) 10.98(1 \mathrm{H}$, s, CONHCO), $8.45(1 \mathrm{H}, \mathrm{d}, J 8.3 \mathrm{~Hz}, \mathrm{NH}), 7.81(2 \mathrm{H}, \mathrm{m}, \mathrm{Ph}), 7.50(3 \mathrm{H}, \mathrm{m}, \mathrm{Ph}), 5.83(3 \mathrm{H}, \mathrm{m}$, $\left.\mathrm{CH}=\mathrm{CH}, \mathrm{CH}-\mathrm{N}_{\text {base }}\right), 5.07(1 \mathrm{H}, \mathrm{m}, \mathrm{CH}-\mathrm{N}), 2.70\left(1 \mathrm{H}, \mathrm{m}, \mathrm{CH}_{2}\right), 2.06\left(3 \mathrm{H}, \mathrm{s}, \mathrm{CH}_{3}\right), 1.96(1 \mathrm{H}, \mathrm{m}$, $\mathrm{CH}_{2}$ ), $1.78\left(3 \mathrm{H}, \mathrm{s}, \mathrm{CH}_{3}\right) ; \delta_{\mathrm{C}}(75 \mathrm{MHz}, \mathrm{DMSO}) 164.8(\mathrm{~s}), 163.7$ (s), 150.7 (s), 146.4 (d), 134.4 (s), 132.6 (d), 132.3 (d), 128.4 (d), 126.9 (d), 104.1 (d), 54.9 (d), 53.7 (d), 34.7 (t), 16.0 (q), 10.3 (q). 


\section{Acknowledgements}

Financial support by University of Pavia (Fondo d'Ateneo per la Ricerca, FAR) and MIUR (PRIN 2005) is gratefully acknowledged.

\section{References}

1. (a) Jeong, L. S.; Lee, J. A. Antiviral Chem. Chemotherapy 2004, 15, 235. (b) Ferrier, R. J. Carbohydrate Chem. 2003, 34, 248. (c) Ferrier, R. J.; Blatter, R.; Filed, R. A.; Furneaux, R. H.; Gardiner, J. M.; Hoberg, J. O.; Kartha, K. P. R.; Tilbrook, D. M. G.; Tyler, P. C.; Wightman, R. H. Carbohydrate Chem. 2002, 33, 275. (d) Zhu, X.-F. Nucleosides, Nucleotides \& Nucleic Acids 2000, 19, 651. (e) Marquez, V. E.; Lim, M.-I. Med. Res. Rev. 1986, $6,1$.

2. (a) Huryn, D. M.; Okabe, M. Chem. Rev. 1992, 92, 1745. (b) Borthwich, A. D.; Briggadike, K. Tetrahedron 1992, 48, 571. (c) Agrofoglio, L.; Suhas, E.; Farese, A.; Condom, R.; Challand, S. A.; Earl, R. A.; Guedj, R. Tetrahedron 1994, 50, 10611. (d) Balzarini, J.; Baumgartner, H.; Bodenteich, M.; De Clercq, E.; Griengl, H. J. Med. Chem. 1989, 32, 1861.

3. (a) Siddiqi, S. M.; Chen, X.; Schneller, S. W. Nucleosides \& Nucleotides 1993, 12, 267. (b) Dyatkina, N.; Semizarov, D.; Victorova, L.; Krayevsky, A.; Theil, F.; v. Janta-Lipinski, M. Biophysics/Biochemistry 1995, 723. (c) Burlina, F.; Favre, A.; Fourrey, J.-L.; Thomas, M. Bioorg. Med. Chem. Lett. 1997, 7, 247. (d) Rajappan, V. P.; Schneller, S. W. Tetrahedron 2001, 57, 9049. (e) Trost, B. M.; Madsen, R.; Guile, S. D. Tetrahedron Lett. 1997, 38, 1707. (f) Ye, S.; Rezende, M. M.; Deng, W.-P.; Herbert, B.; Daly, J. W.; Johnson, R. A.; Kirk, K. L. J. Med. Chem. 2004, 47, 1207.

4. (a) Velcicky, J.; Lanver, A.; Lex, J.; Prokop, A.; Wieder, T.; Schmalz, H.-G. Chem. Eur. J. 2004, 10, 5087. (b) Santana, L.; Tejeira, M.; Uriarte, E.; Balzarini, J.; De Clercq, E. Eur. J. Med. Chem. 2002, 37, 755.

5. (a) Jin, D. Z.; Kwon, S. H.; Moon, H. R.; Gunaga, P.; Kim, H. O.; Kim, D.-K.; Chun, M. W.; Jeong, L.S. Bioorg. Med. Chem. 2004, 12, 1101. (b) Sriram, D.; Yogeeswari, P.; Srichakravarthy, N.; Ratan Bal, T. Bioorg. Med. Chem. Lett. 2004, 14, 1085. (c) Dyatkina, N.; Theil, F.; v. Janta-Lipinski, M. Tetrahedron 1995, 51, 761. (d) Gundersen, L.-L.; Benneche, T.; Undheim, K. Tetrahedron Lett. 1992, 33, 1085. (e) MacKeith, R. A.; McCague, R.; Olivo, H. F.; Palmer, C. F.; Roberts, S. M. J. Chem. Soc. Perkin trans. 1 1993, 313. (f) Crimmins, M. T.; King, B. W. J. Org. Chem. 1996, 61, 4192.

6. (a) Loiseleur, O.; Ritson, D.; Nina, M.; Crowley, P.; Wagner, T.; Hanessian, S. J. Org. Chem. 2007, 72, 6353. (b) Saville-Stones, E. A.; Turner, R. M.; Lindell, S. D.; Jennings, N. S.; Head, J. C.; Carver, D. S. Tetrahedron 1994, 50, 6695. (c) Matsumura, Y.; Morisawa, Y.; Yasuda, A.; Uchida, K.; Jpn. Kokai Tokkyo Koho 1989, JP 01172376. (d) Matsumura, Y.; Morisawa, Y.; Yasuda, A.; Uchida, K.; Jpn. Kokai Tokkyo Koho 1989, JP 01022853. (e) 
Morisawa, Y.; Yasuda, A.; Nakayama, T.; Uchida, K.; Jpn. Kokai Tokkyo Koho 1988, JP 63203638.

7. (a) Stauffer, C. S.; Bhaket, P.; Fothergill, A. W.; Rinaldi, M. G.; Datta, A. J. Org. Chem. 2007, 72, 9991. (b) Zhang, D.; Miller, M. J. J. Org. Chem. 1998, 63, 755-759. (c) Miller, M. J.; Jin, B.; Warshakoon, N. C.; Gage, J. L. Proceedings from the $226^{\text {th }}$ ACS National Meeting New York, NY, September 7-11, 2003. (d) Roberts, S. M.; Williamson, N. M. Curr. Org. Chem. 1997, 1, 1. (e) Mahmoudian, M.; Baines, B. S; Dawson, M. J.; Lawrence, G. C. Enzyme Micr. Tech. 1992, 14, 911.

8. (a) Ikejiri, M.; Ohshima, T.; Fukushima, A.; Shimotohno, K.; Maruyama, T. Bioorg. Med. Chem. Lett. 2008, 18, 4638. Recent Review: (b) De Clercq, E. Nat. Rev. Drug Discov. 2007, 6, 1001. (c) Iannazzo, D.; Piperno, A.; Romeo, G.; Romeo, R.; Chiacchio, U.; Rescifina, A.; Balestrieri, E.; Macchi, B.; Mastino, A.; Cortese, R. Bioorg. Med. Chem. 2008, 16, 96109615. (d) Chiacchio, U.; Mastino, A.; Merino, P.; Romeo, G. PCT Int. Appl. 2007, 45, WO2007065883 A1 20070614.

9. (a) Perigaud, C.; Gosselin, G.; Imbach, J.-L. Nucleosides \& Nucleotides 1992, 11, 903. (b) Kitade, Y.; Kojima, H.; Zulfiqur, F.; Kim, H. S.; Wataya, Y. Bioorg. Med. Chem. Lett. 2003, 13, 3963. (c) Ramesh, N. G.; Klunder, A. J. H.; Zwanenburg, B. J. Org. Chem. 1999, 64, 3635. (d) Wu, J.; Schneller, S. W.; Seley, K. L.; DeClerq, E. Heterocycles 1998, 47, 757. (e) Siddiqi, S. M.; Raissian, M.; Schneller, S. W.; Ikeda, S.; Snoeck, R.; Andrei, G.; Balzarini, J.; DeClerq, E. Bioorg. Med. Chem. Lett. 1993, 3, 663. (f) Da Silva, A. D.; Coimbra, E. S.; Fourrey, J. L.; Machado, A. S.; Robert-Gero, M. Tetrahedron Lett. 1993, 34, 6745. (g) Koga, M.; Schneller, S. W. Tetrahedron Lett. 1990, 31, 5861.

10. (a) Quadrelli, P.; Scrocchi, R.; Caramella, P.; Rescifina, A.; Piperno, A. Tetrahedron 2004, 60, 3643. (b) Quadrelli, P.; Piccanello, A.; Vazquez Martinez, N.; Bovio, B.; Mella, M. Tetrahedron 2006, 62, 7370. (c) Quadrelli, P.; Piccanello, A.; Mella, M., Corsaro, A.; Pistarà, V. Tetrahedron 2008, 64, 3541. (d) Quadrelli, P.; Mella, M.; Carosso, S.; Bovio, B.; Caramella, P. Eur. J. Org. Chem. 2007, 6003. (e) Quadrelli, P.; Mella, M.; Assanelli, G.; Piccanello, A. Tetrahedron 2008, 62, 7312.

11. (a) Kirby, G. W. Chem. Soc. Rev. 1977, 6, 1. (b) Vogt, P. F.; Miller, M. J. Tetrahedron 1998, 54, 1317. (c) Boger, L.; Weinreb, S. M. Hetero Diels-Alder Methodology in Organic Synthesis, Academic Press: San Diego, 1987.

12. Quadrelli, P.; Fassardi, V.; Cardarelli, A.; Caramella, P. Eur. J. Org. Chem. 2002, 2058.

13. (a) Jiang, M. X.-W.; Warshakoon, N. C.; Miller, M. J. J. Org. Chem 2005, 70, 2824. (b) Saville-Stones, E. A.; Lindell, S. D.; Jennings, N. S.; Head, J. C.; Ford, M. J. J. Chem. Soc. Perkin Trans. 1 1991, 2603. (c) Miller, A.; Procter, G. Tetrahedron Lett. 1990, 1043. (d) Trost, B. M.; Kuo, G.-H.; Benneche, T. J. Am. Chem. Soc. 1988, 110, 621.

14. (a) Mulvihill, M. J.; Gaye, J. L.; Miller, M. J. J. Org. Chem. 1998, 63, 3357. (b) Hattori, H.; Abbas, A. A.; Kobayashi, Y. Chem. Commun. 2004, 884. (c) Popescu, A.; Hörnfeldt, A. B.; Gronowitz, S Nucleosides \& Nucleotides. 1995, 14, 1233. (d) Kapeller, H.; Marschner, C.; Weißenbacher, M.; Griengl, H. Tetrahedron. 1998, 54, 1439. (e) Koga, M.; Schneller, S. W. 
J. Org. Chem. 1993, 58, 6471. (f) Dyatkina, N.; Costisella, B.; Theil, F.; Janta-Lipinski, M. Tetrahedron Letters. 1994, 35, 1961. (g) Curran, T. T. Synthetic Comm. 1996, 26, 1209.

15. Sirisoma, N. S.; Woster, P. M. Tetrahedron Lett. 1998, 39, 1489.

16. Ghosh, A.; Ritter, A. R.; Miller, M. J. J. Org. Chem. 1995, 60, 5808.

17. (a) Cools, M.; De Clercq, E. Biochem. Pharmacol. 1989, 38, 1061. (b) Patil, S. D.; Schneller, S. W.; Hosoya, M.; Snoeck, R.; Andrei, G.; Balzarini, J.; De Clercq, E. J. Med. Chem. 1992, 35, 3372 .

18. Tsuji, J. Palladium Reagents and Catalysts Wiley: Chichester, 1995; pp. 290-422.

19. (a) Hattori, H.; Abbas, A. A.; Kobayashi, Y. Chem. Commun. 2004, 884. (b) Kapeller, H.; Marschner, C.; Weißenbacher, M.; Griengl, H. Tetrahedron 1998, 54, 1439. (c) Koga, M.; Schneller, S. W. J. Org. Chem. 1993, 58, 6471.

20. (a) Ishikura, M.; Murakami, A.; Katagiri, N. Org. Biomol. Chem. 2003, 1, 452. (b) Katagiri, N.; Yamatoya, Y.; Ishikura, M. Tetrahedron Lett. 1999, 40, 9069. (c) Salvatori, D.; Volpini, R.; Vicenzetti, S.; Vita, A.; Costanzi, S.; Lambertucci, C.; Cristalli, G.; Vittori, S. Bioorg. Med. Chem. 2002, 10, 2973. 